Article

\title{
Analysis of the Efficiency of a Batch Boiler and Emissions of Harmful Substances during Combustion of Various Types of Wood
}

\author{
Grzegorz Pełka ${ }^{1}$, Mateusz Wygoda ${ }^{2, *(D)}$, Wojciech Luboń ${ }^{1}$, Przemysław Pachytel ${ }^{1}$, Artur Jachimowski ${ }^{2}$, \\ Marcin Paprocki ${ }^{2}$, Paweł Wyczesany ${ }^{2}$ and Jarosław Kotyza ${ }^{1}$
}

1 Faculty of Geology, Geophysics and Environmental Protection, AGH University of Science and Technology, 30-059 Cracow, Poland; pelka@agh.edu.pl (G.P.); lubon@agh.edu.pl (W.L.); p.pachytel@insytytutmiekinia.pl (P.P.); kotyza@agh.edu.pl (J.K.)

2 Department of Product Technology and Ecology, College of Management and Quality Sciences, Cracow University of Economics, ul. Rakowicka 27, 31-510 Cracow, Poland; artur.jachimowski@uek.krakow.pl (A.J.); paprockm@uek.krakow.pl (M.P.); wyczesap@uek.krakow.pl (P.W.)

* Correspondence: wygodam@uek.krakow.pl

\section{check for} updates

Citation: Pełka, G.; Wygoda, M.; Luboń, W.; Pachytel, P.; Jachimowski, A.; Paprocki, M.; Wyczesany, P.; Kotyza, J. Analysis of the Efficiency of a Batch Boiler and Emissions of Harmful Substances during Combustion of Various Types of Wood. Energies 2021, 14, 6783. https://doi.org/10.3390/en14206783

Academic Editors: Francesco Nocera and Mark S. Laser

Received: 8 September 2021

Accepted: 14 October 2021

Published: 18 October 2021

Publisher's Note: MDPI stays neutral with regard to jurisdictional claims in published maps and institutional affiliations.

Copyright: (c) 2021 by the authors. Licensee MDPI, Basel, Switzerland. This article is an open access article distributed under the terms and conditions of the Creative Commons Attribution (CC BY) license (https:// creativecommons.org/licenses/by/ $4.0 /)$.

\begin{abstract}
In the paper, the authors focused on the environmental problems of pollution emissions caused by households using batch boilers fired with solid fuels. The aim of this study is to analyse the course of changes in the actual efficiency and emission of a solid fuel updraft boiler, the most popular type of batch boilers used in Poland in recent years. The subject of analysis is the comparison of the values of atmospheric emissions of harmful substances depending on the type of wood burnt in the boiler. The investigation comprises the combustion characteristics of three types of woody biomass (in billets), i.e., pine, birch, and beech. Based on the carried out research of all billets, the beech has the lowest values of $\mathrm{CO}\left(3497 \mathrm{mg} / \mathrm{m}^{3}\right)$ and particulate matter $\left(116.9 \mathrm{mg} / \mathrm{m}^{3}\right)$. Despite this, obtained results exceed the current permissible limits based on the standard PN:EN 303-5:2012. The highest efficiency $(54.13 \%)$ was obtained for birch billets, the lowest for pine $(45.13 \%)$. The research has shown that the real heating efficiency during the combustion of wood, irrespective of the type of wood being burnt, is low. To summarise, the outdated installations contribute to air pollution several times higher, which indicates the need to replace inefficient heat sources using solid fuels with modern equipment that meets the most stringent standards.
\end{abstract}

Keywords: emission; combustion; dust; efficiency; wood; boiler; environment; ecology

\section{Introduction}

Poor air quality is one of the most important environmental issues in Poland today. A common occurrence in this area is the phenomenon of emissions from a low stack, caused by any pollutants generated by fuel combustion, emitted into the atmosphere at the height of up to $40 \mathrm{~m}$. Attention in this regard is mainly devoted to the municipal and household sector, which accounts for over $80 \%$ of the effect of this phenomenon in Poland [1-3]. The national emission inventories for 2015-2016 prepared by the National Centre for Emissions Management (KOBiZE) show that non-industrial combustion processes, i.e., the municipal and household sector, has the largest share in the total annual national emission of carbon monoxide, i.e., $61.3 \%$; total particulate matter (TPM) - 44.2\%; PM2.548.2\%; PM10-45.3\%; dioxins-52.3\%, and polycyclic aromatic hydrocarbons (PAHs) $88 \%$ [4]. This is contributed by the operation of inefficient heating systems and the use of low-quality fuels. To counteract emissions from low sources, numerous legal acts are implemented at the national and local government levels, and existing standards and regulations are updated on an ongoing basis. Examples of such solutions include the AntiSmog Resolution for Małopolska (Lesser Poland) [5] and the PN-EN 303-5:2012 standard [6]. 
This translates into the implementation of increasingly advanced technological solutions in the heating industry.

In many countries around the world, the use of biomass is an increasingly popular solution to reduce coal combustion and increase renewable energy use in installations [7]. The increase in its importance is mainly due to concerns about global warming. As a result, biomass is becoming an increasingly justifiable fuel to use in two sectors: large-scale commercial power generation and small households [8]. While commercial installations use specially processed biomass (in the form of woodchips, pellets, or briquettes), in the case of the household sector, especially in Europe, the largest part of the energy is derived from raw biomass, the combustion of which results in high emissions of fine particulate matter [9-11]. International agreements and EU directives oblige member states to reduce greenhouse gas emissions, primarily carbon dioxide. Regrettably, a huge number of boilers still in operation and using solid fuels are characterised by high energy losses. One of the effective ways to diagnose the reasons behind the low energy efficiency of such boilers, as well as to develop solutions to increase the same, is to analyse the efficiency of these devices under different conditions [12,13]. The efficiency of a heating device is nothing but the ratio of the energy returned to the system as a result of combustion to the chemical energy contained in the fuel supplied. This relation is measured and reported with very high accuracy, but it depends on many factors, such as the efficiency of the device, the fuel parameters, and the technological solutions used. This makes it very difficult to determine unambiguous results. Methods for calculating the efficiency of heating devices have not changed much in recent years, but as a result of increasingly stringent environmental regulations and as a result of technological developments, more and more emphasis is placed on balancing losses and improving the efficiency of heating devices $[14,15]$.

\subsection{Legal Acts Regulating the Air Quality in Poland}

The problem of air pollution is nowadays a very frequently raised issue at almost every level of society. It is obvious that every person wants to breathe fresh and healthy air. The first decade of the 21st century was marked by a huge increase in energy demand. In addition, the emphasis on compact buildings, especially in urban areas, and the high prices of suitable quality energy resources led to a significant deterioration in air quality in Poland at that time. As a consequence of society's struggle to improve air quality and reduce emissions of pollutants responsible for smog, a number of legal changes have been made to the requirements for boilers and heating installations. As a result of these actions, a significant improvement in this area can be noticed in recent years $[16,17]$.

The most important legal acts currently in effect in Poland and concerning environmental protection are:

- Act of 27 April 2001, Environmental Protection Law, which defines the principles of environmental protection, as well as the conditions for the use of natural resources taking into account the requirements of sustainable development [18];

- Directive 2008/50/EC of the European Parliament and of the Council of 21 May 2008 on ambient air quality and cleaner air for Europe [19];

- National Air Protection Programme (KPOP) until 2020 (with an outlook to 2030) aiming to improve air quality throughout Poland, especially in areas with the highest concentrations of pollutants and also highly urbanised areas [20].

The main factor that led to the poor air quality in Poland was the lack of legal regulations on the quality of fuels and energy efficiency of heating equipment allowed for sale before 2017. This situation is now gradually changing under central and local legislation [21]. Previously, there were only a few standards in force concerning the certification of solid fuel boilers. The first of these was the PN-70/H-83136 standard 'heating boilers' [22]. It defined the concept of a boiler, classified them according to the heated area and their design, and sorted out issues concerning the combustion process (e.g., top-fired boiler or automatic boiler). It was then replaced by PN-EN 303-5:2002 [23]. At present, its amended version is in force: PN-EN 303-5:2012 [6]. It defines the requirements on the efficiency and 
emissions for carbon monoxide (CO), organic gaseous compounds (OGC), and dust for solid fuel boilers with a heat output of up to $500 \mathrm{~kW}$. However, none of the above standards regulated the marketing of boilers that failed to meet their requirements.

The situation changed as late as 1 October 2017 when the Regulation of the Minister of Development and Finance of 1 August 2017 [24] on the requirements for solid fuel boilers, which specified the CO, OGC, and dust emission limits for boilers launched in the market, came into force and prohibited the use of an emergency grate. However, the regulation was not precise, and therefore an amendment was required. Since 3 March 2019, the Regulation of the Minister of Entrepreneurship and Technology of 21 February 2019 amending the regulation on the requirements for solid fuel boilers [25] has been in force, aiming to fill in the gaps and inaccuracies. Another change towards the legal regulation in this area was the entry into force of the Act of 16 October 2019 amending the Environmental Protection Law, which, inter alia, prohibited the marketing of batch boilers that do not meet any standards. In addition, as of the beginning of 2020, the requirements set out in Directive 2009/125/EC of the European Parliament, and of the Council of 21 October 2009 establishing a framework for the setting of ecodesign requirements for energy-related products [26] took effect in Poland. The directive contains information on the limit values of nitrogen oxide emissions and also introduces the concept of seasonal energy efficiency, i.e., the ratio, expressed in \%, of the amount of heat supplied by an appliance throughout the heating season to the energy consumed by that appliance during the year [27].

In addition to central legal acts, numerous local regulations, such as anti-smog resolutions, should also be mentioned. In short, these are regulations passed by provincial assemblies and aimed at improving air quality in a particular area [27]. The first province where such a resolution was passed [5] was Małopolskie.

\subsection{The Technology of Wood Combustion Process}

For woody biomass, the combustion process has been known for a very long time. At first glance, it may seem very simple and obvious, but from the technical point of view, there are many different boiler designs adapted to work with specific types of fuel. The use of substitutes, not fully adapted to the design of the boiler, significantly affects the quality of the process of combustion and, consequently, increases emissions and reduces the efficiency of the device.

The commonly understood combustion of wood and fossil fuels is divided into a number of processes that are hardly noticeable at first glance. They are separated according to the temperature of the fuel during the combustion process. Additionally, it can be considered through the prism the feed availability, its pretreatment, fuel properties, and combustor types, followed by operational issues, greenhouse gases, and other harmful emissions trends, as well as ash properties and use [28]. Three characteristic stages can be distinguished [29]:

- Drying, a process occurring at temperatures up to $100{ }^{\circ} \mathrm{C}$ when the energy supplied to the fuel is used to evaporate water;

- Degassing of volatile components, their ignition, and combustion, taking place in the temperature range from 200 to $500^{\circ} \mathrm{C}$;

- Actual combustion of coke or charcoal resulting from pyrolysis, occurring at temperatures above $500{ }^{\circ} \mathrm{C}$.

Taking into account the efficiency of boilers depending on their construction and design, the following can be distinguished, respectively: boilers with updraft-Figure 1a, boilers with downdraft combustion-Figure $1 \mathrm{~b}$, and gasification boilers-Figure 1c. 
a)

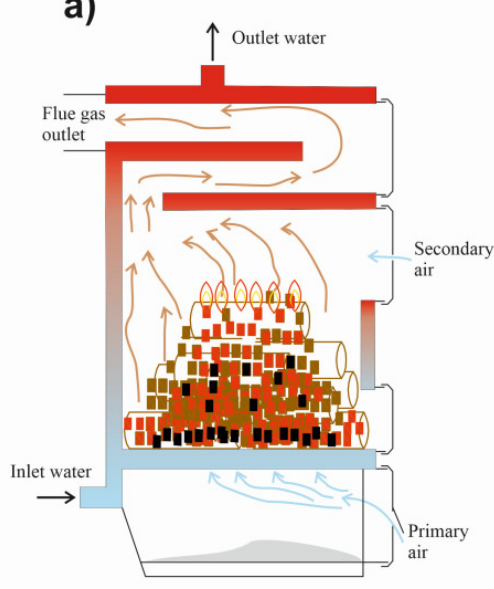

b)

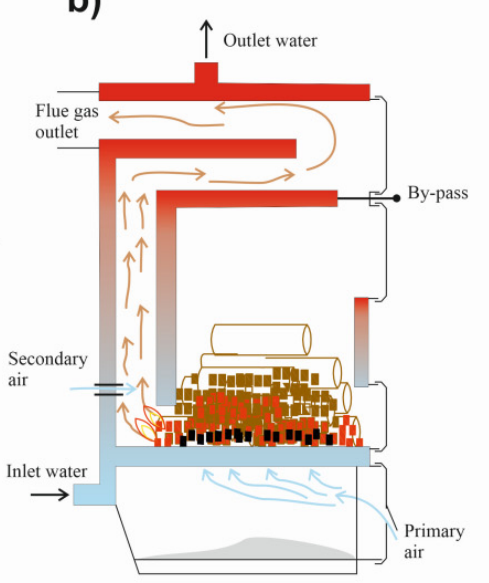

c)

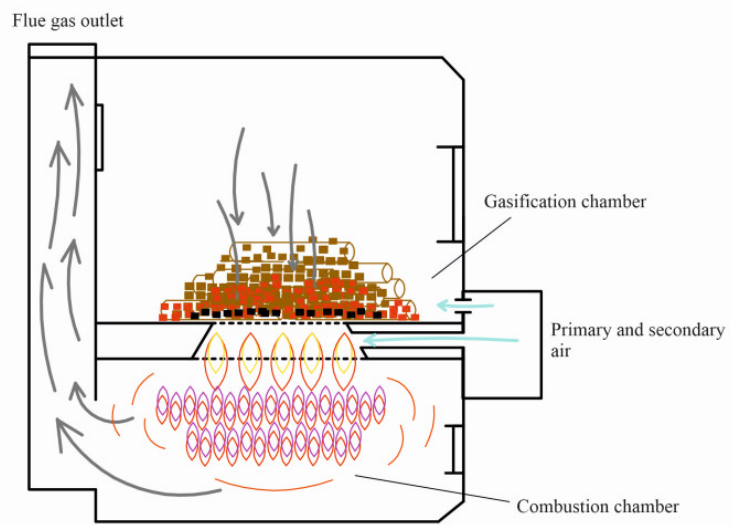

Figure 1. Boiler designs: (a) boilers with updraft combustion, reproduced from the work of [30]; (b) boilers with downdraft combustion, reproduced from the work of [30]; (c) gasification boilers, reproduced from the work of [31].

In the first case, boilers with updraft combustion (Figure 1a) are the cheapest, simplest, and most popular solution in Poland. In this type of boiler, the feeding chamber and combustion chamber are connected to each other. With this technology, the fuel is burnt in the entire volume of the bed, which makes the process fast but very difficult to control. This design makes it possible to burn almost any type of solid fuel. Unfortunately, many households take advantage of this fact and burn fuels of inferior quality or even waste, which contributes enormously to the phenomenon of low stack emissions of dust and unburnt gases formed during fuel pyrolysis. The maximum efficiency of such devices usually does not exceed $80 \%$, which translates into very low seasonal efficiency, often not exceeding 50\% [32], and the combustion time depends mainly on the capacity of the loading chamber. For such boilers, air blowers are often used. The process of thermal decomposition of the fuel into volatile organic compounds takes place immediately after firing, which in the case of wood accounts for up to $70 \%$ of the supplied energy. In the case of boilers of this type, significant decreases in efficiency can be observed when operating below the rated capacity. This situation occurs commonly in real conditions. A solution that can eliminate this cause is the use of a heat buffer, which allows the device to operate at rated output regardless of the instantaneous demand for heat. As a result, a higher temperature in the combustion chamber and an overall better quality of the process itself reduces emissions of harmful substances and improves boiler efficiency [33]. In batch boilers with combustion in the entire volume of the bed (updraft boiler), all these stages occur simultaneously. It results in huge energy losses due to the emission of unburnt volatile matter into the atmosphere [34].

Another technological solution is provided by boilers with downdraft combustion (Figure $1 \mathrm{~b}$ ). This solution is more technologically advanced as compared with boilers with upper combustion and has much higher efficiency, even up to $85 \%$, which does not show large decreases when operating below the rated capacity. It is also characterised by lower rates of emissions of harmful substances. The combustion chamber in such boilers is often made of chamotte or ceramic material in order to maintain a high temperature during the entire combustion cycle [35].

The most expensive and the most technologically advanced solution is provided by gasification boilers (Figure 1c). Heat generation in such devices proceeds differently than in the case of classic wood biomass boilers. In the gasification technology, wood is heated and reacts chemically with oxidants (oxygen, atmospheric air, water vapour, and $\mathrm{CO}_{2}$ ) under oxygen-limited conditions as compared with the stoichiometric demand required to completely burn the fuel. Heat loss in this process is small compared with conventional combustion. The flue gas leaving the appliance contains no solid particles 
because the volatile compounds turn into gas, being a mixture of methane, carbon oxides, and hydrogen. There only remains ash. During the gasification process, four basic chemical processes are distinguished [36]:

- $\quad$ Drying of the fuel;

- Pyrolysis and devolatilisation;

- Oxidation of volatiles under oxygen-limited conditions;

- Reduction in gases by contact with glowing char.

The resulting gas then enters the burner nozzle and is mixed with the oxygen in the supplied air. As a result of this process, it is ignited.

\subsection{Emissions from Solid Fuel Boilers in the Case of Biomass Combustion}

Solid fuels are energy carriers commonly used for heating purposes in Poland. In 2018, as many as $43 \%$ of all households were heated with solid fuel boilers [37]. As a result of the combustion of solid fuels, a huge amount of harmful substances gets into the atmosphere, and these include carbon, sulphur, and nitrogen oxides, as well as particulate matter in all forms.

The fuels most commonly used for household heating in Poland are hard coal and biomass in the form of dried wood billets [37]. They are comprised of three basic substances, a combustible (organic) substance, a mineral one, and water. The proportion of each element in the fuel varies and depends on the type of fuel as well as the degree of carbonisation. The structure of the proportion of carbon, hydrogen, and oxygen depends on the degree of metamorphism. The higher the degree of metamorphism, the higher the carbon content and the lower the oxygen and hydrogen content. This parameter has no impact on compounds such as sulphur or nitrogen [38]. Therefore, it can be concluded that biomass and hard coal differ significantly with regard to the content of the particular elements, which affects not only their different calorific value but also the proportion of volatile matter and ash concentration (Figure 2).

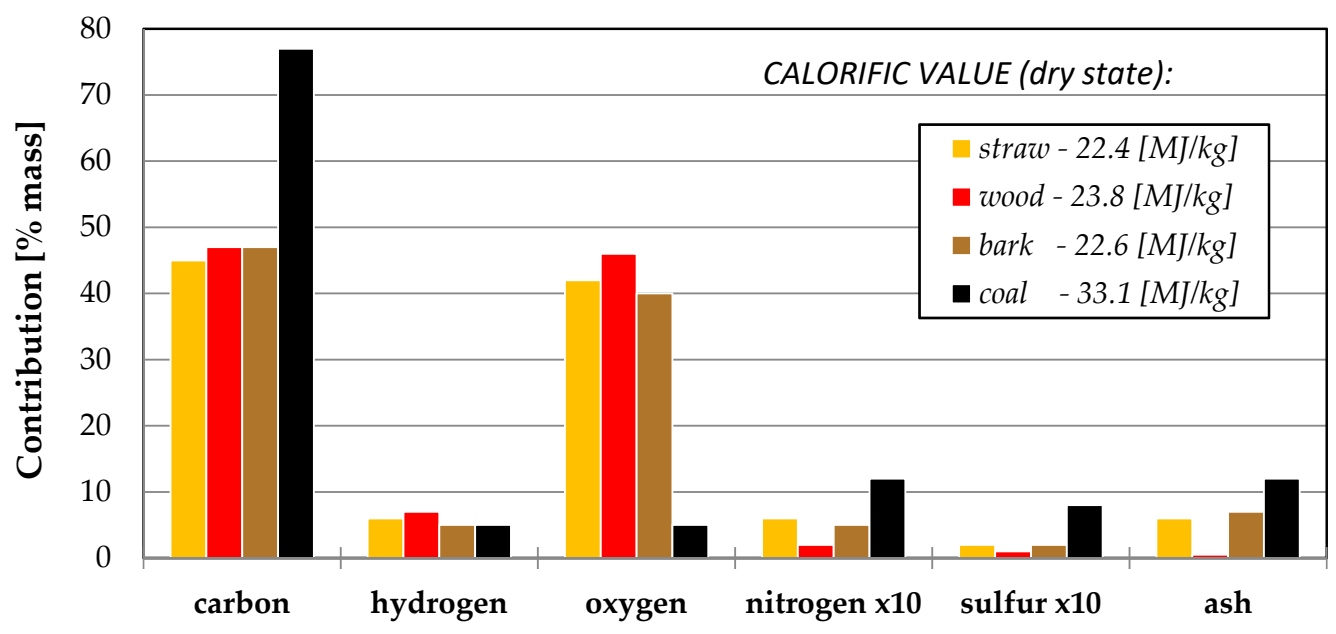

Figure 2. Proportion of substances depending on solid fuel, reproduced from the work of [32].

In the case of wood, significant differences in the chemical composition can be observed even within a single species, and this is due to such factors as the density of the stand, the anatomical structure, the age of the tree, and the type of habitat [39]. The most harmful substance emitted during biomass combustion is carbon monoxide (CO). Its emission levels depend mainly on the quality of the fuel (humidity and volatile content) and the quality of the combustion process (the air-fuel ratio, combustion temperature, and boiler technology). On the other hand, it can be concluded that the lower the CO emission, the more efficient this process is. It is closer to complete combustion [40]. 
Currently, however, most public attention is drawn by dust emission. According to research, its ambient concentrations are most affected by emissions from low sources [16,41]. Particularly dangerous is particulate matter $\mathrm{PM}_{10}$ and $\mathrm{PM}_{2.5}$ containing heavy metals such as cadmium, lead, and arsenic. Additionally, on its surface, there are adsorbed and associated toxins, which include polycyclic aromatic hydrocarbons (PAHs), furans, and dioxins [42]. The dust particles formed as a result of biomass combustion can be divided into organic and inorganic aerosols. Organic particles are formed as a result of incomplete oxidation of fuel. Their amount can be reduced by proper control of the combustion process. An example effective solution is the air staging strategy, which possible decrease in particulate matters smaller than $1 \mathrm{~mm}$ is achievable through adjusting a uniform secondary air module at an appropriate distance from the bed [41]. Inorganic dust, on the other hand, is formed from volatile ash, mainly potassium and chlorine compounds. Their amount in the flue gas depends mainly on the share of each element in the primary composition of the fuel [21].

The formation of these pollutants during combustion depends to the largest extent on parameters such as the composition and type of the fuel, the geometric design and type of the furnace, the temperature in the combustion chamber, and the amount of air supplied to the combustion process [43]. During the combustion of solid fuels, nitrogen oxides $\left(\mathrm{NO}_{\mathrm{x}}\right)$ are also emitted into the atmosphere. There are three mechanisms of nitrogen oxide formation, i.e., fuel, thermal (Zeldovich's), and fast [44-46]. Nitrogen oxides arise mainly from communication sources, and to a much lesser extent, from the combustion of solid fuels

As a result of solid fuel combustion, harmful sulphur dioxide $\left(\mathrm{SO}_{2}\right)$ is also produced, which is the cause of, e.g., acid precipitation. The quantity of its emission depends on the amount of sulphur contained in the burnt fuel. In the case of wood, this amount is very small compared with hard coal and agro-biomass.

\subsection{Characteristics of Wood in the Context of Firewood}

Wood as a fuel can be found in various forms. Depending on the fraction, diameter, and degree of processing, the following are distinguished: billets, sawdust, shavings, woodchips, bark, pellets, and briquettes. Due to the multitude of forms, it is very difficult to adopt an unambiguous and uniform unit of measurement to compare different types of wood fuel [47]. To facilitate the use of the terminology used to describe wood as a fuel, the following units are used:

- $\quad 1 \mathrm{~m}^{3}$ of wood, referring to the volume of solid wood, e.g., cut from a sufficiently thick tree trunk;

- 1 st (stere), defining the volume of wood together with the air contained in the voids between its pieces.

It is worth noting that, e.g., 1 st of sawdust and 1 st of billets characterise completely different volumes of the same type of wood. Another difficulty is the use of mass units. This is affected by two factors, i.e., moisture content and porosity. With regard to $1 \mathrm{~m}^{3}$ of solid wood, the same species with a high water content can weigh many times more compared with dry wood. Porosity, on the other hand, specifies different densities of the tree depending on the species (Table 1). 
Table 1. Wood density depending on the species $[47,48]$.

\begin{tabular}{ccccc}
\hline $\begin{array}{c}\text { Species of } \\
\text { Wood }\end{array}$ & Density & Density & Density & Total Shrinkage \\
\hline - & $\begin{array}{c}\text { Freshly Cut } \\
\text { Wood } \mathbf{Y}_{\mathbf{w}}\end{array}$ & $\begin{array}{c}\text { Air-Seasoned } \\
\text { Wood } \mathbf{Y}_{\mathbf{1 5}}\end{array}$ & $\begin{array}{c}\text { Completely Dry } \\
\text { Wood } \mathbf{Y}_{\mathbf{a}}\end{array}$ & $\begin{array}{c}\text { Raw Wood } \\
\text { Volume } \mathbf{a}_{\mathbf{v}}\end{array}$ \\
\hline $\mathbf{-}$ & $\mathbf{g} \mathbf{c m}^{\mathbf{3}}$ & $\mathbf{g} / \mathbf{c m}^{\mathbf{3}}$ & $\mathbf{g} / \mathbf{c m}^{\mathbf{3}}$ & $\mathbf{\%}$ \\
\hline Beech & 0.99 & 0.73 & 0.69 & 17.6 \\
Oak & 1.08 & 0.71 & 0.66 & 12.6 \\
Birch & 0.94 & 0.65 & 0.61 & 14.2 \\
Alder & 0.69 & 0.53 & 0.49 & 12.6 \\
Pine & 0.70 & 0.55 & 0.48 & 12.0 \\
Spruce & 0.74 & 0.47 & 0.43 & 11.7 \\
Fir & 1.00 & 0.45 & 0.41 & \\
\hline
\end{tabular}

According to statistical data, approximately 19 million $\mathrm{m}^{3}$ of timber are felled in Poland every year for commercial purposes. It has been estimated that out of $100 \mathrm{~m}^{3}$ of wood obtained as a result of logging, brushwood accounts for $15 \mathrm{~m}^{3}$, bark-10 $\mathrm{m}^{3}$, sawdust $-19 \mathrm{~m}^{3}$, and large timber- $20 \mathrm{~m}^{3}$ [49]. From this, it follows that manufacturing sawn timber products involves a very large loss of raw material. Therefore, it can be assumed that waste material that can be used for energy purposes accounts for approximately $80 \%$ of the total wood mass [50].

The form of firewood most commonly used in boilers and fireplaces is billets. Due to the higher density and lower content of resins that produce smoke when burnt, hardwood is preferred. For combustion, the wood used should be in the air-dry condition, i.e., excess water accumulated in the pore spaces of the vascular cambium has been removed by drying, and the remaining moisture has reached equilibrium with atmospheric moisture. In the case of woody biomass, it is estimated that immediately after felling, the proportion of water in the wood mass is about $60 \%$. The natural drying process is usually lengthy and highly dependent on ambient conditions (Table 2).

Table 2. Average moisture content in wood logs during drying [34].

\begin{tabular}{cc}
\hline Drying Time & Relative Humidity \\
\hline Months & $\%$ \\
\hline 0 & 60 \\
3 & 40 \\
6 & 35 \\
9 & 30 \\
12 & 25 \\
18 & 18 \\
24 & 15 \\
\hline
\end{tabular}

According to a report [51,52] on the state of forests in Poland, $29.6 \%$ of the total area of Poland is covered by forests [52]. In the case of the Małopolskie (Lesser Poland) Province, the forest cover is $28.7 \%$. Throughout the country, coniferous species dominate, occupying $68.2 \%$ of the total forest area, of which as much as $58 \%$ are pine trees. It is only in the south of the country, in the Małopolskie and Podkarpackie Provinces, that deciduous trees have a greater share. The dominant species are fir (coniferous) and beech (deciduous) (Figure 3). 


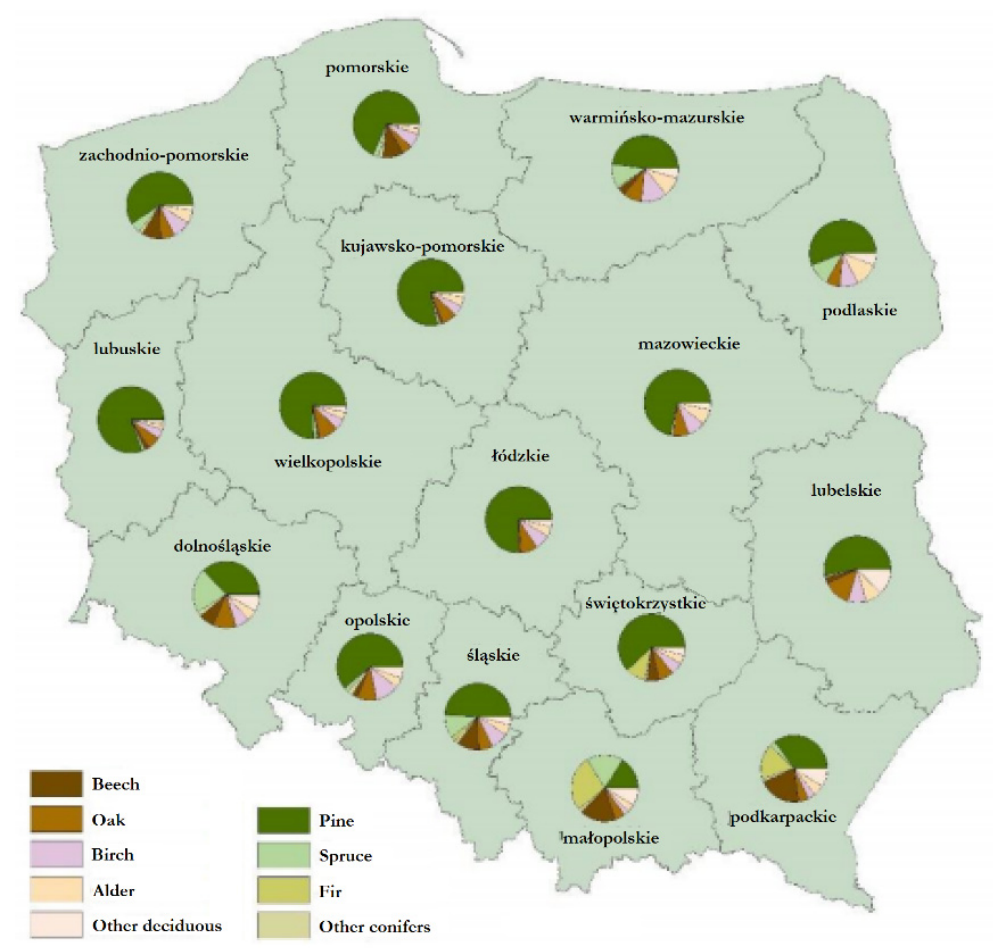

Figure 3. Spatial distribution of stands in Poland. Division into species in provinces. Status for 2019 [52].

\subsection{The Aim and Approach of the Paper}

The aim of this study is to analyse the course of changes in the actual efficiency of a Class 1 solid fuel updraft boiler according to PN-EN 303-5:2002 [6], which represents the group of batch boilers that are still commonly in operation in Poland and they combust hard coal and wood billets, where hard coal is the basic fuel, and wood billets are secondary fuel according to the manual of tested boiler [53]. The subject of analysis is an investigation of the misuse of coal-fired domestic boilers most commonly used in Poland to burn wood fuels and the associated negative factors: low efficiency and high pollution. The obtained data are used to compare the values of atmospheric emissions of harmful substances depending on the type of wood burnt in the batch boiler, against the available standard PN-EN 303-5:2012. The investigation comprises the combustion characteristics of three types of woody biomass (in billets), i.e., pine, birch, and beech. The data obtained show how outdated installations contribute to the phenomenon of emissions from low sources and indicate the need to replace inefficient heat sources using solid fuels with modern equipment that meets the most stringent standards.

\section{Materials and Methods}

This section describes the three specified solid wood fuels. The test stands together with the measuring devices and the measurement methods. In order to clearly present the effects of the comprehensive and advanced testing, the authors divided this section into three subsections with a precise and detailed description.

\subsection{Materials-Types of Wood Solid Fuels}

In accordance with the basic information presented in the introduction to this experimental study, the authors chose three types of typical wood solid fuels. These are birch, pine, and beech billets.

Due to its high calorific value and very suitable combustibility, birch is a popular fuel species. It has a bark content of about $12 \%$. It is one of the fastest drying firewood species. Another advantage of this wood species is that it is easy to split; it is also widely available. 
Beech wood is the most popular type of fireplace wood in Poland. It has a high calorific value and very high density, and so it burns for a long time and gives much heat (due to its density). It is characterised by a relatively low proportion of bark, up to a maximum of $7 \%$. Other advantages are that it splits easily and has a short drying time. Its biggest disadvantages include its limited supply in the market.

Pine, on the other hand, is a coniferous species characterised by low density, high resin content, which adversely affects the combustion process, and a bark content of up to $9 \%$. This wood burns very quickly, and burning resin produces large amounts of soot that settles on the inner parts of the boiler and chimney. During combustion, pinewood crackles and sparkles in a specific way. For this reason, it is not suitable for fireplaces, but it can be burnt in boilers and furnaces with a closed combustion chamber. Pine chips are ideal as firelighters [54].

For the purpose of this study, an analysis was made of physicochemical parameters and composition of flue gases discharged from the boiler as a result of the combustion of three types of firewood, i.e., beech, birch, and pine. Due to their different structures and chemical compositions, different types of biomass show clear differences in the values of particular physicochemical parameters (Table 3).

Table 3. Average values of selected parameters of the biomass tested for a relative humidity of $15 \%[48,55]$.

\begin{tabular}{ccccc}
\hline Parameter & Unit & Beech & Birch & Pine \\
\hline Calorific value & $\mathrm{GJ} / \mathrm{m}^{3}$ & 10.49 & 9.38 & 7.73 \\
Ash content & $\%$ & 0.5 & 0.6 & 1.8 \\
Share of volatile parts & $\%$ & $>70$ & $>70$ & $>75$ \\
Hydrogen content & $\%$ & 6.2 & 6.1 & 6.3 \\
Carbon element content & $\%$ & 47.9 & 47.1 & 49.8 \\
Nitrogen content & $\%$ & 0.22 & 0.42 & 0.13 \\
Bark content & $\%$ & $<7$ & $<12$ & $<9$ \\
\hline
\end{tabular}

\subsection{The Test Stand with Measuring Devices}

This part of the study presents the measuring devices and the test stand used to obtain experimental results.

\subsubsection{The Analysis of the Physicochemical Parameters}

The tests aimed at determining the physicochemical parameters of the types of wood under analysis were carried out in a laboratory located at the Centre for Sustainable Development and Energy Conservation at the Faculty of Geology, Geophysics and Environmental Protection of the AGH University of Science and Technology (WGGiOŚ AGH) in Miękinia. In the centre, there are conducted lectures for students and workshops for people interested in the field of use of solid biofuels and low emission causes and also testing and research to reach real data for it [56-58]. Its equipment allows accurate determination of energy parameters of solid fuels. The following equipment was used:

- Moisture analyser-Radwag MA50.R;

- Muffle furnace-Nabertherm L 9/11/SKW;

- Calorimeter-KL-11 Mikado.

The Radwag MA50.R moisture analyser is designed for measuring relative humidity, dry mass content in small samples and determining the mass of loads. It allows analysis of fuel with a mass of up to $50 \mathrm{~g}$ with an accuracy of $1 \mathrm{mg}$. The drying process takes place on a drying pan located inside the analyser, which is heated by a metal heater. The maximum temperature that can be obtained in this moisture analyser is $160{ }^{\circ} \mathrm{C}$. During the tests, the samples were dried at a temperature of approximately $120^{\circ} \mathrm{C}$ until all the moisture evaporated from them. This causes evaporation of the moisture contained in the sample. The device is equipped with an LCD display that allows keeping track of the 
results. Compared with other conventional methods, e.g., distillation or extraction, the use of a moisture analyser significantly facilitates and shortens the process of measurement.

The device used to determine the content of ash and volatile matter in fuels is the Nabertherm L 9/11/SKW muffle furnace. Muffle furnaces are commonly used in laboratories that carry out the processes of torrefaction, incineration, melting, and annealing of various materials. An important part of the design of the device is a ceramic muffle that is heated on four sides and ensures uniform temperature distribution inside the furnace. A special controller makes it possible to set an appropriate time of heating, thanks to which it is possible to achieve the desired temperature increase over time that is crucial for the proper course of the process of incineration and degassing of the samples. The maximum operating temperature of the device is $1100{ }^{\circ} \mathrm{C}$.

The KL-11 Mikado calorimeter was used to determine the gross calorific value of the wood tested based on which the net calorific value was then calculated. The principle of operation of the device is based on measuring the increase in the temperature of water in which the calorimetric bomb is immersed during the complete combustion of a fuel sample located inside it. The process takes place in an oxygen atmosphere at a pressure of 20 bars.

\subsubsection{POLoNES—Mobile Laboratory}

The installation of the updraft batch boiler used for the combustion process is located inside the POLoNES mobile laboratory (Figure 4). The nominal heating capacity of the boiler is $12 \mathrm{~kW}$ (when hard coal is combusted), and the nominal efficiency for it is 78\% [59]. The boiler has a thermostatically on-off blower fan of primary air, and there is no secondary air supply.

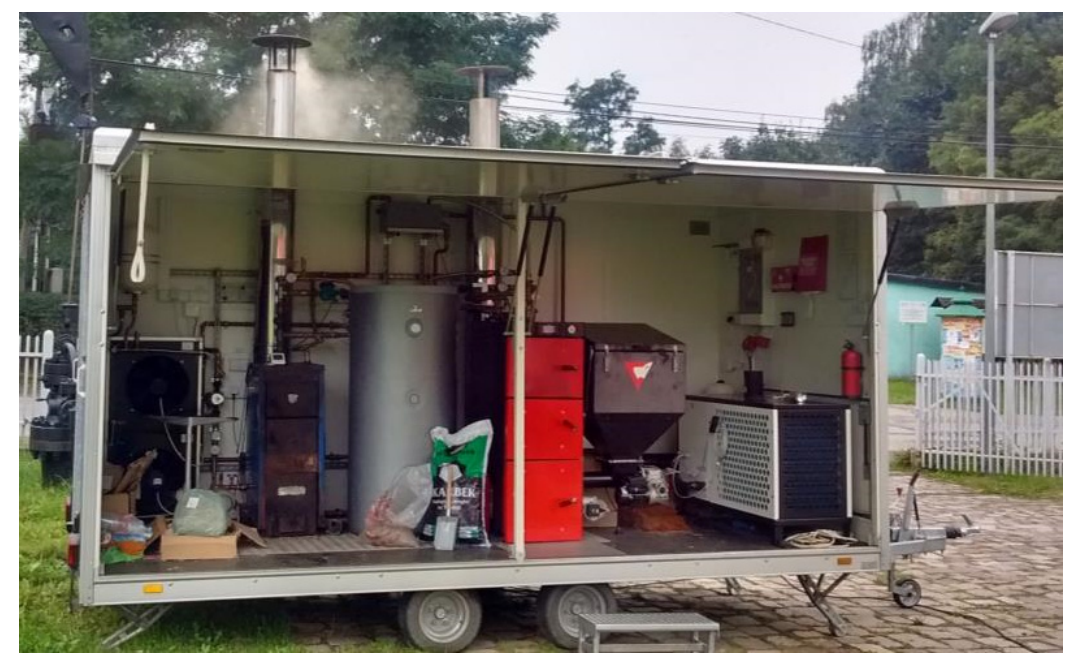

Figure 4. The POLoNEs mobile laboratory.

According to the rating plate on this boiler, it was certified in accordance with the now obsolete standard PN-EN 303:5:2002 [6], according to which it met the requirements for Class 1 (for hard coal as a fuel). The boiler operates in an open system with supply and return parameters of $75 / 55^{\circ} \mathrm{C}$, made of uninsulated copper pipes with a diameter of $28 \mathrm{~mm}$. In addition to the standard boiler room equipment, the system includes appropriate instrumentation to measure the various parameters of the combustion process. This consists of a flow meter, a heat meter, and Pt100 temperature sensors. All the readings, such as inlet and outlet temperatures, flow rate, and instantaneous heating power, are recorded in real time with the Ekontrol software provided by the Hewalex company. The boiler's flue gas discharge system consists of a $3.5 \mathrm{~m}$ high telescopic chimney made of stainless steel with specially made ports to measure the flue gases by means of special analysers. The installation is equipped with an active cooling system consisting of a $20 \mathrm{~kW}$ glycol fan 
cooler operating. The detailed information about technical parameters, drawings, etc., are in the work of [59].

\subsubsection{Testo 350 Flue Gas Analyser}

A Testo 350 flue gas analyser was used to analyse the composition of the exhaust gas. It is a portable analyser used to measure substances such as $\mathrm{CO}, \mathrm{CO}_{2}$, and $\mathrm{O}_{2}$. The analyser is characterised by a wide measuring range, up to 40,000 ppm for CO. Sensors are tested every six months and calibrated as required, according to Testo 350 Manual [60]. The EasyHeat software supplied by the manufacturer makes it possible to integrate the analyser with a computer in order to record the results in real time and also to save them later.

\subsubsection{The FSM Particulate Matter Measurement System}

In order to determine the dust and particulate emissions during combustion, an FSM particulate matter meter was used. The basic principle of measurement is to determine the mass of dust absorbed by the filter of the device in relation to the volume of flue gas sucked in. This is performed by weighing the filter before and after the measurement. The weighing is performed by means of a moisture analyser. The operation of the FSM is possible through the OPTIMA 7 unit designed especially for this dust meter; the unit is responsible for all the necessary calculations in connection with measuring not only particles but also $\mathrm{CO}$ and oxygen. Additionally, it is also responsible for the process of weighing filters as it is connected with the moisture analyser by means of a special cable and for the management of the sample database, FSM diagnostics, and communication with the software on the computer. The design of the device and the flue gas path diagram are shown in a schematic drawing.

\subsection{Methodology of the Research}

In this part, the authors present the methods used to measure the relative and absolute humidity, and to determine the content of ash and volatile components, as well as to determine the calorific value and the efficiency of the boiler; the description also includes a flue gas analysis and the measurement of dust emissions.

\subsubsection{Moisture Content}

There are many different factors that determine the possibility of using biomass as an energy carrier. The most important of them is its moisture content. It is what largely determines the calorific value of biomass. The higher the water contents of the fuel, the lower the calorific value $[61,62]$. The moisture content of wood is defined as the ratio of the mass of water contained in it to the mass of that wood, and it is expressed as a percentage (Equation (1)):

$$
M_{C}=\frac{m_{w}}{m_{p}} \cdot 100 \%=\frac{m_{p}-m_{s}}{m_{p}} \cdot 100 \%
$$

where: $M_{C}$-moisture content, $\% ; m_{w}$-mass of water in the sample, $g ; m_{p}$ - original mass of the sample, $\mathrm{g} ; m_{\mathrm{s}}$-mass of the dry sample, $\mathrm{g}$.

It is the value of this parameter that is crucial when determining the calorific value of biomass and the ash content. For determining moisture content, a moisture analyser was used. The samples were dried at a temperature of approximately $120{ }^{\circ} \mathrm{C}$ until all the moisture evaporated from them. The process was terminated automatically by the device when no further decrease in sample mass was observed. Then, the results were read from the balance display, and using the formulas presented above, the moisture content of the wood samples was calculated.

\subsubsection{Determination of Ash Content}

Ash is the residue obtained from complete combustion and torrefaction of the sample. It consists of mineral compounds. Its content and composition affect the heat of combustion 
of the fuel, and therefore its suitability for industrial use [63-66]. It forms as small particles usually carried with flue gases and heavier fractions falling into the ash pan.

The determination of ash content in the test samples was based on the guidelines contained in EN 14:775:2009 Solid biofuels, determination of ash content [67]. Knowing the relative humidity, the ash content was calculated using the following Equation (2):

$$
A=\frac{m_{p s}}{m_{p}} \cdot\left(1-M_{C}\right) \cdot 100 \%
$$

where: $A$-ash content, $\% ; m_{p}$ —mass of the dry sample, $g ; m_{p s}$-mass of the sample after burning, $\mathrm{g} ; M_{C}$-moisture content.

\subsubsection{Determination of Volatile Matter}

Volatile matter is gases that are formed in the initial phase of combustion when fuel is heated in the absence of air, i.e., pyrolysis. They are formed by the thermal decomposition of organic compounds contained in the combustible mass. These are mainly hydrocarbons, carbon oxides, and hydrogen. The proportion of volatile matter in fuel has a great influence on the combustion process and also determines the ease of ignition of the energy carrier. Fuels with a high volatile content ignite more readily.

The method of determining volatile matter is precisely described in PN-G-04516:1998 Solid fuels, determination of volatile content [68]. The volatile content in the tested samples was calculated from the Equation (3):

$$
V=\frac{m_{p}-m_{p w}}{m_{p}} \cdot\left(1-M_{C}\right) \cdot 100 \%
$$

where: $V$-volatile content, $\% ; m_{p}$-original mass of the sample, g; $m_{p w}$-mass of the sample after torrefaction, $\mathrm{g} ; M_{\mathrm{C}}$-moisture content.

\subsubsection{Determination of Net Calorific Value}

In order to determine the gross calorific value of the types of wood analysed for the purpose of this work, a KL-11 Mikado automatic calorimeter was used. The measurement method is based on the complete combustion of a fuel sample inside a calorimetric bomb filled with oxygen under pressure and placed in a water calorimeter. The test was performed in accordance with the operating instructions of the device. Knowing the gross calorific value, hydrogen content, moisture, and ash content of a given fuel sample, its net calorific value can be calculated using the appropriate Equation (4):

$$
Q_{i}=Q_{s}-2442\left(W_{w}+8.94 H^{d a f}\left(1-M_{C}-A\right)\right)\left[\frac{\mathrm{kJ}}{\mathrm{kg}}\right]
$$

where: $Q_{i}$ —net calorific value, $\mathrm{kJ} / \mathrm{kg} ; Q_{s}$-gross calorific value, $\mathrm{kJ} / \mathrm{kg} ; M_{C}$ 一moisture content; $A$-ash content, -; $H^{\text {daf }}$ - proportion of hydrogen in the fuel on a dry and ash-free basis, for the wood value, is 0.06 ; value: 2442 - evaporation heat of water at $25^{\circ} \mathrm{C}, \mathrm{kJ} / \mathrm{kg}$; value: 8.94 - the ratio of molar mass of water and molecular hydrogen.

\subsubsection{The Combustion Process and Determination of Efficiency, and Flue Gas Analysis}

In order to determine the actual heating efficiency of an updraft batch boiler, the following methodology was developed. Using a balance, $10 \mathrm{~kg}$ of each individual wood type was weighed out. The boiler furnace was thoroughly cleaned of all residues and impurities from previous combustion cycles. The temperature sensors were calibrated, and the capacity of the circulating pump was adjusted so that the fluid flow was suitable for the installation. For the purpose of the test, a glycol cooler was used to simulate the operation of heat consumers. The use of the GECO controller integrated with the Ekontrol software made it was possible to record the operating parameters of the installation in real time [69]. 
For the firing process, $1 \mathrm{~kg}$ of wood was used, previously chopped into suitably small billets. After the fuel was ignited, approximately $4 \mathrm{~kg}$ of dry wood was added in the form of billets, and the blower fan was switched on. When the appropriate operating temperature was reached $\left(75 / 55^{\circ} \mathrm{C}\right)$, the cooler was switched on to maintain as far as possible constant parameters. Then another batch with a mass of approximately $3 \mathrm{~kg}$ was placed inside the combustion chamber. At this point, the analysis of flue gases and particulate matter was also commenced, during which care was taken not to open the boiler door in order not to disturb the measurements. Once the measurement was completed, the remaining fuel was placed inside the combustion chamber. At this stage, the running power of the glycol cooler was reduced to $40 \%$. The whole process continued until the reading of the heat output of the unit was $0 \mathrm{~kW}$, which meant that the fuel had burnt out and all the heat generated was returned to the system. Then, the value of the heat generated during the process was read from the heat meter and compared with the theoretical amount of chemical energy contained in the burnt fuel as determined by the previous physicochemical analysis in order to calculate the actual efficiency of the unit. Once the system cooled down, the furnace and ash pan were cleaned of any combustion by-products, and the next type of wood was burnt in the same way.

\subsubsection{Emission Measurements}

The measurement of the harmful substances escaping with flue gases from the boiler during the combustion process (Figure 5) was made using Testo 350 and FSM analysers.

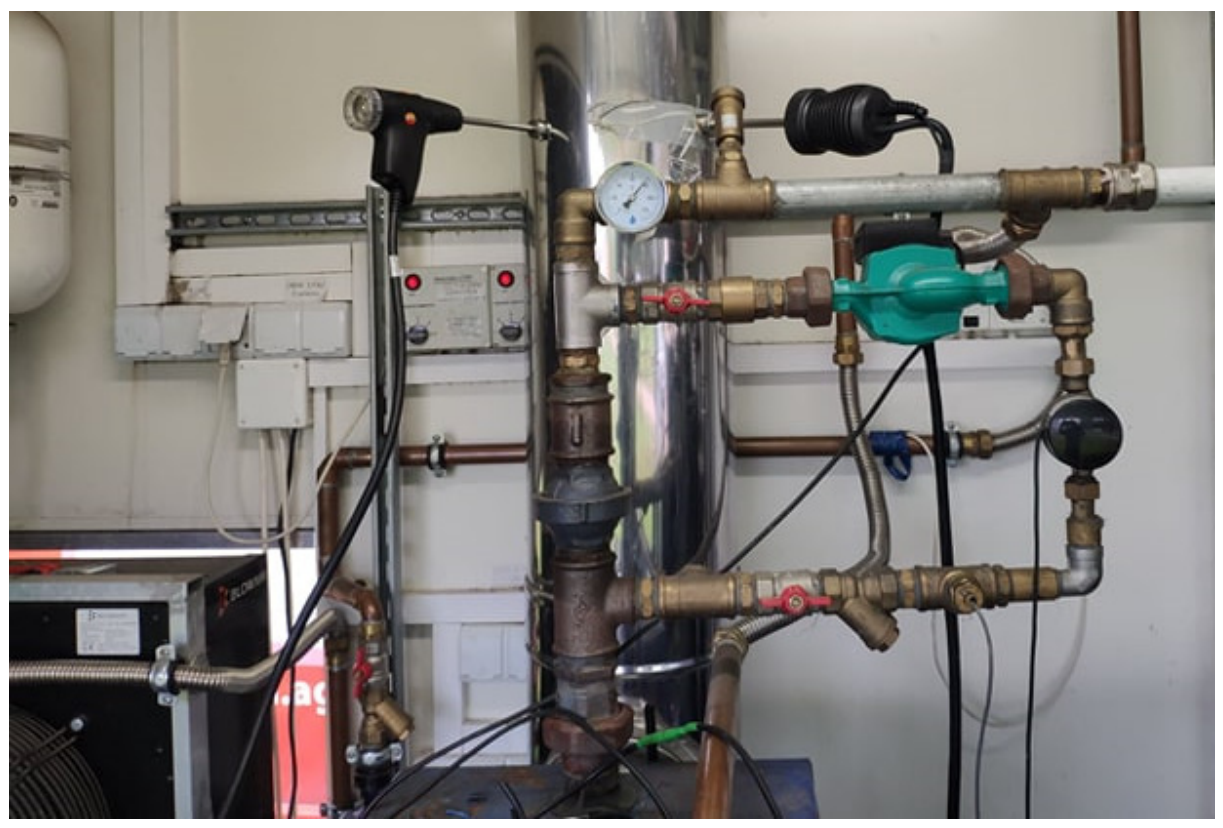

Figure 5. Chimney with flue gas probes installed. Testo 350 probe on the left, FSM probe on the right.

In the case of the first analyser, the measurement process was in progress from the moment of firing up to the moment of shutting down the boiler. During this time, the level of each substance in the flue gas was recorded on an ongoing basis and stored on a computer connected to the analyser. The emission values during the cycle were presented in graphs while the averaged values were tabulated. In the case of particulate matter measurement with the FSM, the cycle lasted 35 min and was carried out when the system was operating at rated capacity with operating parameters of $75 / 55^{\circ} \mathrm{C}$. Due to the fact that the particulate matter measurement system uses the weighing method, the filter papers placed inside the probe were weighed before and after the measurement. The device automatically registers the volume of the flue gas stream flowing through it, and based on these data, it determines the dust content per $1 \mathrm{~m}^{3}$ of flue gas. Unfortunately, this device 
does not provide real-time traceability of the readings. It needs to be highlighted that all readings have been converted to $10 \%$ reference oxygen in the flue gas as indicated in PN-EN 303-5:2012 [6].

\section{Results of Experimental Tests}

In this section, the results of tests for each of the fuels are discussed individually.

\subsection{Experimental Results for Birch}

The first type of woody biomass analyzed was birch wood. As can be seen from the physicochemical analysis, the average moisture content in the samples is $11.86 \%$. The ash content is at $0.84 \%$. The sample is characterized by a high proportion of volatile components, i.e., $75.19 \%$. The net calorific value is $16.07 \mathrm{MJ} / \mathrm{kg}$, which is relatively high for unprocessed woody biomass (Table 4).

Table 4. The physicochemical parameters of the tested birch wood billet.

\begin{tabular}{|c|c|c|c|c|c|}
\hline Parameter & Symbol & Unit & $\begin{array}{c}\text { Subsequent } \\
\text { Measurements }\end{array}$ & $\begin{array}{c}\text { Average } \\
\text { Value }\end{array}$ & $\begin{array}{l}\text { Standard } \\
\text { Deviation }\end{array}$ \\
\hline Moisture content & $\mathrm{M}_{\mathrm{C}}$ & $\%$ & $\begin{array}{l}12.11 \\
11.15 \\
11.99\end{array}$ & 11.86 & \pm 0.52 \\
\hline Ash content & $\mathrm{A}$ & $\%$ & $\begin{array}{l}0.92 \\
0.82 \\
0.78\end{array}$ & 0.84 & \pm 0.07 \\
\hline $\begin{array}{l}\text { Volatile matter } \\
\text { content }\end{array}$ & $\mathrm{V}$ & $\%$ & $\begin{array}{l}75.41 \\
75.69 \\
74.47\end{array}$ & 75.19 & \pm 0.64 \\
\hline Net calorific value & $\mathrm{Q}_{\mathrm{i}}$ & $\mathrm{MJ} / \mathrm{kg}$ & $\begin{array}{l}16.34 \\
16.01 \\
15.86\end{array}$ & 16.07 & \pm 0.25 \\
\hline
\end{tabular}

The combustion process occurred at an ambient temperature of $25^{\circ} \mathrm{C}$ and air humidity of approximately $65 \%$. For the purpose of combustion, $10 \mathrm{~kg}$ of dry birch wood was prepared in the form of billets. The entire combustion process took approximately $2.5 \mathrm{~h}$. The particulate matter measurement period of $35 \mathrm{~min}$ for the boiler operating at nominal capacity is marked with yellow lines on the graph (Figures 6 and 7). For the ignition, $1 \mathrm{~kg}$ of wood in the form of billets with a diameter of 1 to $4 \mathrm{~cm}$ was used. A gas burner was used to facilitate the process. The fuel ignited after only several seconds. Once the fuel was ignited, $4 \mathrm{~kg}$ of billets with a diameter of no more than $12 \mathrm{~cm}$ and length around $30 \mathrm{~cm}$ were added, and the blower fan and circulating pump were switched on.

When the temperature of the outlet reached $70^{\circ} \mathrm{C}$, the cooling system was activated to simulate the energy consumer. Then, another $3 \mathrm{~kg}$ portion of fuel was added, and the dust emission measurement was started for $35 \mathrm{~min}$, during which time the combustion process was not interfered with (Figure 6; Figure 7-first yellow vertical line). After completing the measurement, the remaining wood was added. When the supply and return temperatures were equal, the combustion process was considered complete. The boiler operated at an average heat output of $8.11 \mathrm{~kW}$, with the period of operation at rated output lasting $25 \mathrm{~min}$ when the largest mass of fuel was burnt. Then, as the fuel burnt out, the heat output and temperature of the medium began to gradually decrease. At the end of the process, trace amounts of char with a mass of less than $0.1 \mathrm{~kg}$ were left in the combustion chamber. The heat supply to the system was $87.36 \mathrm{MJ}$. By comparing this with the chemical energy contained in the fuel, which is $160.7 \mathrm{MJ}$, it was calculated that the thermal efficiency of the boiler during the process was $54.13 \%$. 


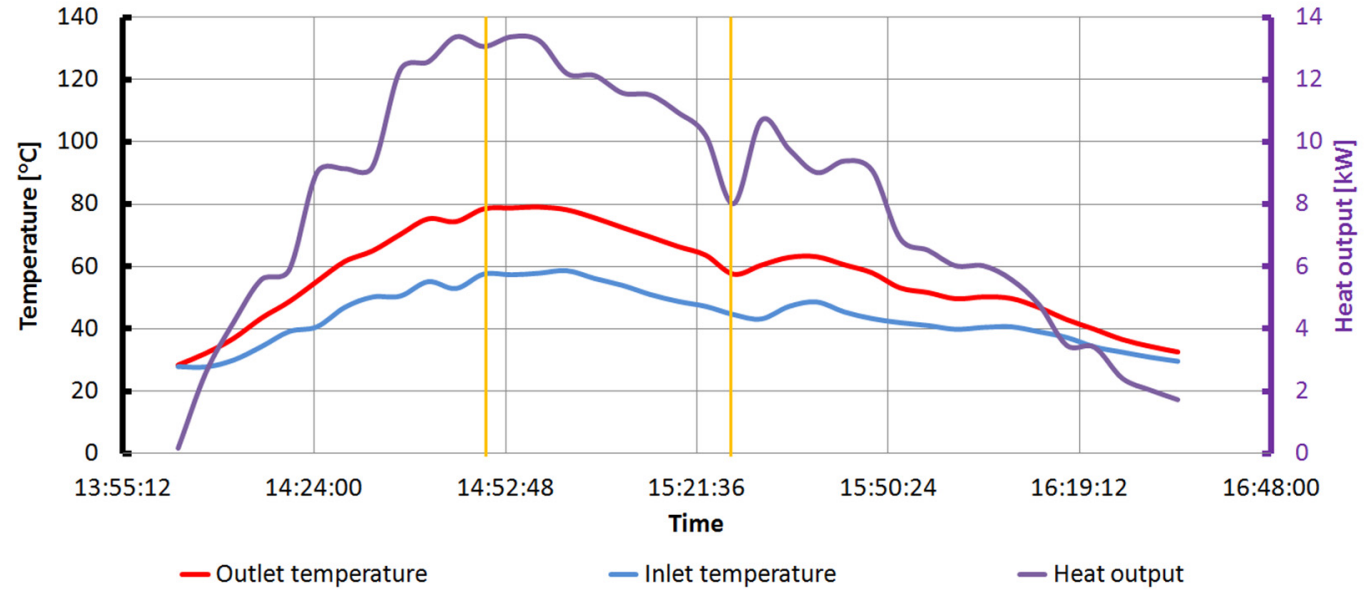

Figure 6. The operation parameters of the system and heat output of the boiler achieved during the combustion of birch wood billet. The yellow lines indicate the dust measurement period.

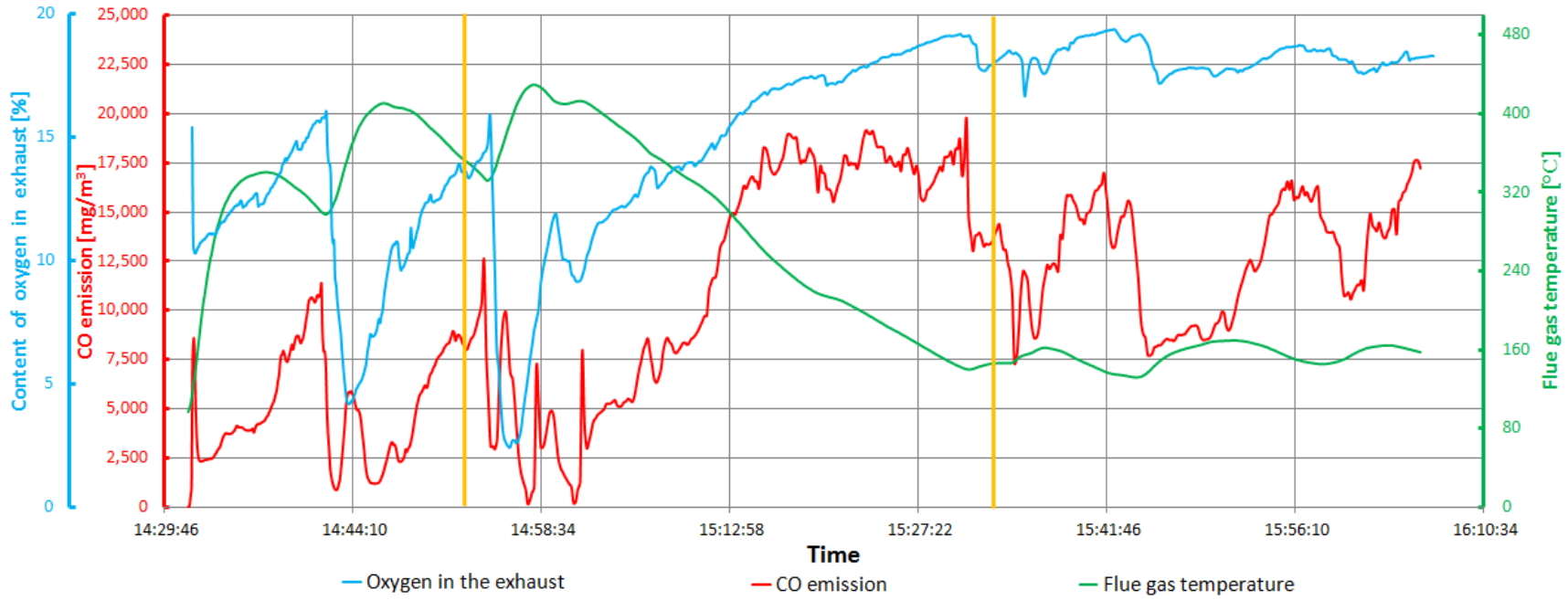

Figure 7. The oxygen in the exhaust and CO emission relative to $10 \%$ oxygen content in flue gas, birch wood billet. The yellow lines indicate the period of dust measurement.

The average $\mathrm{CO}$ emission value relative to the $10 \%$ oxygen content in flue gases was $9495 \mathrm{mg} / \mathrm{m}^{3}$ during the process. The maximum recorded value of $\mathrm{CO}$ was $19,703 \mathrm{mg} / \mathrm{m}^{3}$. Taking into account only the stage when the boiler was operating at the highest capacity (marked with vertical yellow lines on the graph), the values are as follows: $\mathrm{CO}$ emissions: $5196 \mathrm{mg} / \mathrm{m}^{3}$, and the average oxygen content in the flue gas was $10.9 \%$. The maximum CO value recorded was $12,562 \mathrm{mg} / \mathrm{m}^{3}$. As shown in Figure 7, during the period with the highest flue gas temperature is the lowest $\mathrm{CO}$ emission. Particulate matter emission (measured in a time period marked with vertical yellow lines on the graphs) was $152 \mathrm{mg} / \mathrm{m}^{3}\left(\mathrm{O}_{2}\right.$ ref. $10 \%)$.

\subsection{Experimental Results for Pine}

The next type of woody biomass burnt was pine wood. A physicochemical analysis determined the average moisture content of the samples at $10.05 \%$. The content of ash and volatile matter is higher than for birch wood, i.e., $1.13 \%$ and $76.87 \%$, respectively. The net calorific value of the wood was $16.14 \mathrm{MJ} / \mathrm{kg}$, i.e., slightly higher than that of birch (Table 5). 
Table 5. The physicochemical parameters of the tested pine wood billet.

\begin{tabular}{|c|c|c|c|c|c|}
\hline Parameter & Symbol & Unit & $\begin{array}{c}\text { Subsequent } \\
\text { Measurements }\end{array}$ & $\begin{array}{l}\text { Average } \\
\text { Value }\end{array}$ & $\begin{array}{l}\text { Standard } \\
\text { Deviation }\end{array}$ \\
\hline Moisture content & $\mathrm{M}_{\mathrm{C}}$ & $\%$ & $\begin{array}{c}10.91 \\
9.45 \\
9.79\end{array}$ & 10.05 & \pm 0.76 \\
\hline Ash content & $\mathrm{A}$ & $\%$ & $\begin{array}{l}1.24 \\
1.13 \\
1.02\end{array}$ & 1.13 & \pm 0.11 \\
\hline $\begin{array}{l}\text { Volatile matter } \\
\text { content }\end{array}$ & $\mathrm{V}$ & $\%$ & $\begin{array}{l}76.75 \\
77.27 \\
76.59\end{array}$ & 76.87 & \pm 0.36 \\
\hline Net calorific value & $\mathrm{Q}_{\mathrm{i}}$ & $\mathrm{MJ} / \mathrm{kg}$ & $\begin{array}{l}16.47 \\
16.02 \\
15.93\end{array}$ & 16.14 & \pm 0.29 \\
\hline
\end{tabular}

The process of combustion occurred at an ambient temperature of $22{ }^{\circ} \mathrm{C}$ and air humidity of $75 \%$. The wood was burnt in a quantity of $10 \mathrm{~kg}$ in the form of billets with a diameter of $10 \mathrm{~cm}$. The length of the billets was around $30 \mathrm{~cm}$. The entire combustion process took approximately $2 \mathrm{~h}$. The yellow vertical lines indicate the duration of the particulate matter measurement (Figures 8 and 9). The process of burning pine was carried out in a similar way as the process of burning birch. The fuel ignited almost instantly and burnt with a very intense flame. The boiler operated at an average output of $8.16 \mathrm{~kW}$, and the period of operation at rated capacity was approximately $21 \mathrm{~min}$. When burning $5 \mathrm{~kg}$ of pine wood, the outlet water temperature reached $70{ }^{\circ} \mathrm{C}$ very quickly, i.e., after only approximately $16 \mathrm{~min}$ and the rated heat output was reached after $12 \mathrm{~min}$ from the moment of adding the second dose of fuel with a mass of $3 \mathrm{~kg}$. It can be concluded that pine wood burns very quickly.

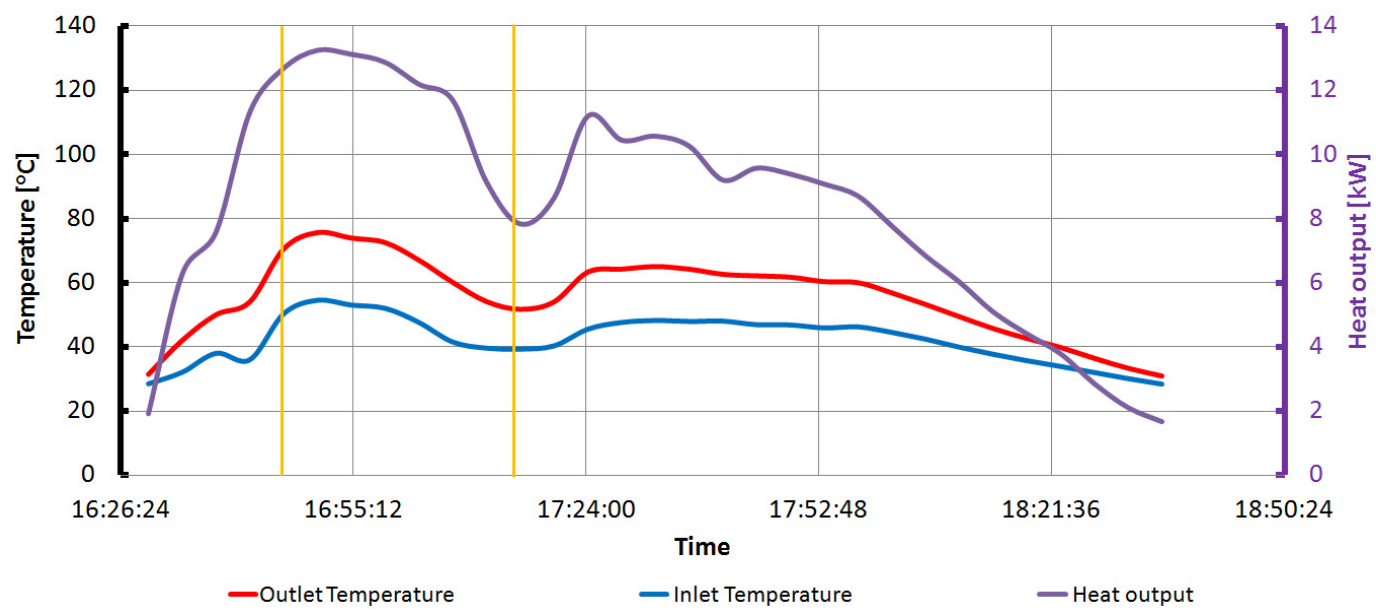

Figure 8. The operation parameters of the system and heat output of the boiler achieved during the combustion of pine wood billet. The yellow lines indicate the dust measurement period.

A rapid drop in heat output, down to $8 \mathrm{~kW}$, and supply water temperature, down to $52{ }^{\circ} \mathrm{C}$, can be observed during the measurement. After the dust measurement process was completed and the last dose of fuel was added, a sudden spike in the heat output of the device, by $3.5 \mathrm{~kW}$, was noted, but after just a few minutes, the heat output began to gradually decrease. At the end of combustion, no amount of char was left on the grate. The heat supplied to the system was $72.85 \mathrm{MJ}$ as compared with the theoretical chemical energy 
contained in the fuel of $161.4 \mathrm{MJ}$, which means that the thermal efficiency of the boiler was $45.13 \%$.

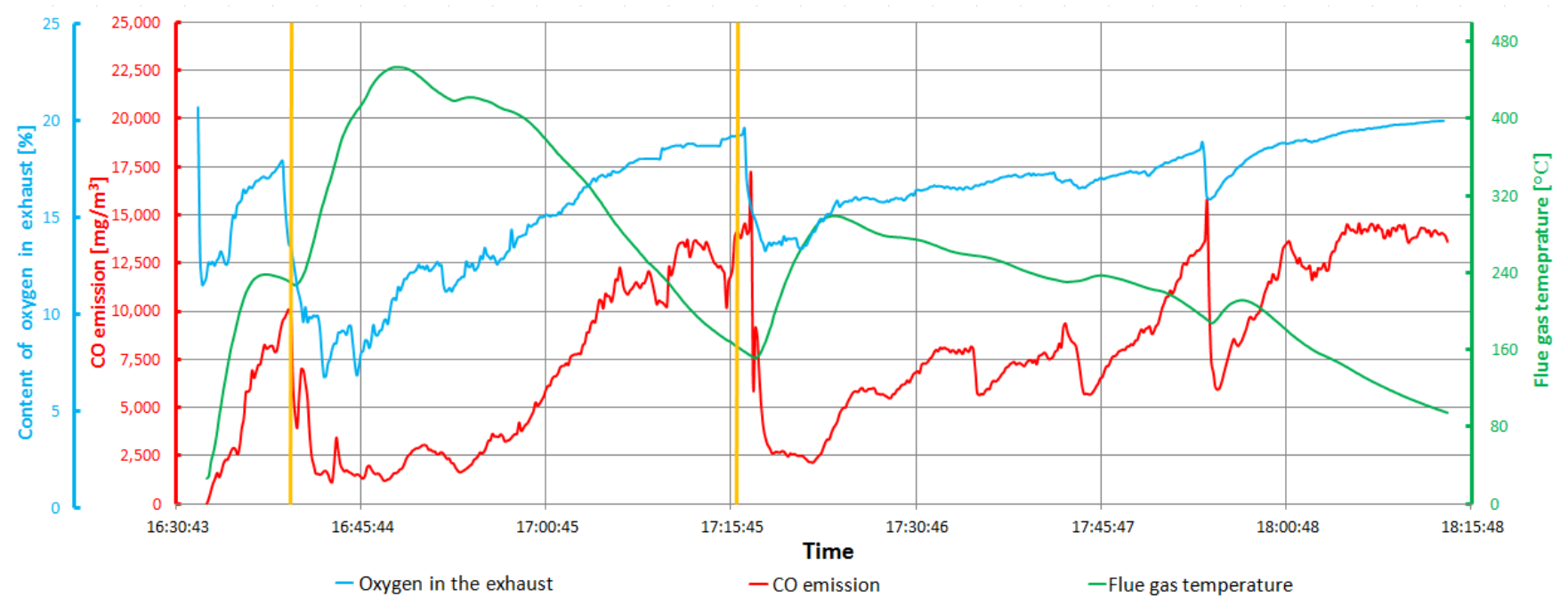

Figure 9. The oxygen in the exhaust and CO emission relative to $10 \%$ oxygen content in flue gas, pine wood billet. The yellow lines indicate the period of dust measurement.

The percentage of oxygen in the flue gas varies between $7 \%$ during the combustion of wood immediately after feeding a dose of fuel and $19 \%$ when it is being burnt out. The average value during the whole process is $15.92 \%$ and $12.32 \%$ during operation at the rated output. The average value of CO, in relation to the oxygen in the flue gas of $10 \%$, was $7684 \mathrm{mg} / \mathrm{m}^{3}$ for CO. The highest recorded emission of CO was equal to $16,932 \mathrm{mg} / \mathrm{m}^{3}$. In the case of boiler operation at the rated capacity (marked on the graph with yellow vertical lines), the emission value for $\mathrm{CO}$ is on average $3497 \mathrm{mg} / \mathrm{m}^{3}$. The highest emission during this period for CO: $8875 \mathrm{mg} / \mathrm{m}^{3}$. The average oxygen content in the flue gas during this period was $12.32 \%$.

Particulate matter emission (measured in a time period marked with vertical yellow lines on the graphs) was $116.9 \mathrm{mg} / \mathrm{m}^{3}\left(10 \% \mathrm{O}_{2}\right.$ ref.).

\subsection{Experimental Results for Beech}

The last fuel analysed was beech wood. Physicochemical analysis showed that the moisture content of the samples was on average $12.5 \%$ (Table 6). The wood is characterised by an ash content of $0.77 \%$ and a volatile fraction of $74.17 \%$. The net calorific value of the samples is equal to $16.14 \mathrm{MJ} / \mathrm{kg}$.

The combustion process occurred at an ambient temperature of $25^{\circ} \mathrm{C}$ and air humidity of approximately $70 \%$. The whole process took approximately $2 \mathrm{~h}$. The particulate matter measurement period is marked on the graph with yellow lines (Figures 10 and 11). For the purpose of combustion, $10 \mathrm{~kg}$ of billets was prepared with the largest diameter of all the fuels combusted, falling within the range of $15-20 \mathrm{~cm}$, the length of billets was around $30 \mathrm{~cm}$. Right from the start, it can be determined that the wood was very massive and heavy compared with pine and birch. The process of kindling the fire took a long time, approximately $3 \mathrm{~min}$. Because of the difficulty with the ignition of beech wood, $0.5 \mathrm{~kg}$ of fine pine billets were used as a firelighter. The fuel burnt very slowly with a small flame. After the first dose of wood was added, a huge amount of smoke was emitted from the chimney during the process of kindling, which indicates degassing of a large amount of volatile components that were not burnt. Once the entire volume of fuel was ignited, the boiler temperature rose rapidly, and the heat output also increased rapidly. Reaching the outlet water temperature of $70{ }^{\circ} \mathrm{C}$ occurred $16 \mathrm{~min}$ after ignition while reaching the rated heat output occurred after approximately $20 \mathrm{~min}$. 
Table 6. The physicochemical parameters of tested beech wood billet.

\begin{tabular}{|c|c|c|c|c|c|}
\hline Parameter & Symbol & Unit & $\begin{array}{c}\text { Subsequent } \\
\text { Measurements }\end{array}$ & $\begin{array}{l}\text { Average } \\
\text { Value }\end{array}$ & $\begin{array}{l}\text { Standard } \\
\text { Deviation }\end{array}$ \\
\hline Moisture content & $\mathrm{M}_{\mathrm{C}}$ & $\%$ & $\begin{array}{l}13.15 \\
12.26 \\
12.10\end{array}$ & 12.5 & \pm 0.57 \\
\hline Ash content & $\mathrm{A}$ & $\%$ & $\begin{array}{l}0.86 \\
0.75 \\
0.70\end{array}$ & 0.77 & \pm 0.08 \\
\hline $\begin{array}{l}\text { Volatile matter } \\
\text { content }\end{array}$ & $\mathrm{V}$ & $\%$ & $\begin{array}{l}74.21 \\
74.39 \\
73.91\end{array}$ & 74.17 & \pm 0.24 \\
\hline Net calorific value & $\mathrm{Q}_{\mathrm{i}}$ & $\mathrm{MJ} / \mathrm{kg}$ & $\begin{array}{l}16.34 \\
16.11 \\
15.97\end{array}$ & 16.14 & \pm 0.19 \\
\hline
\end{tabular}

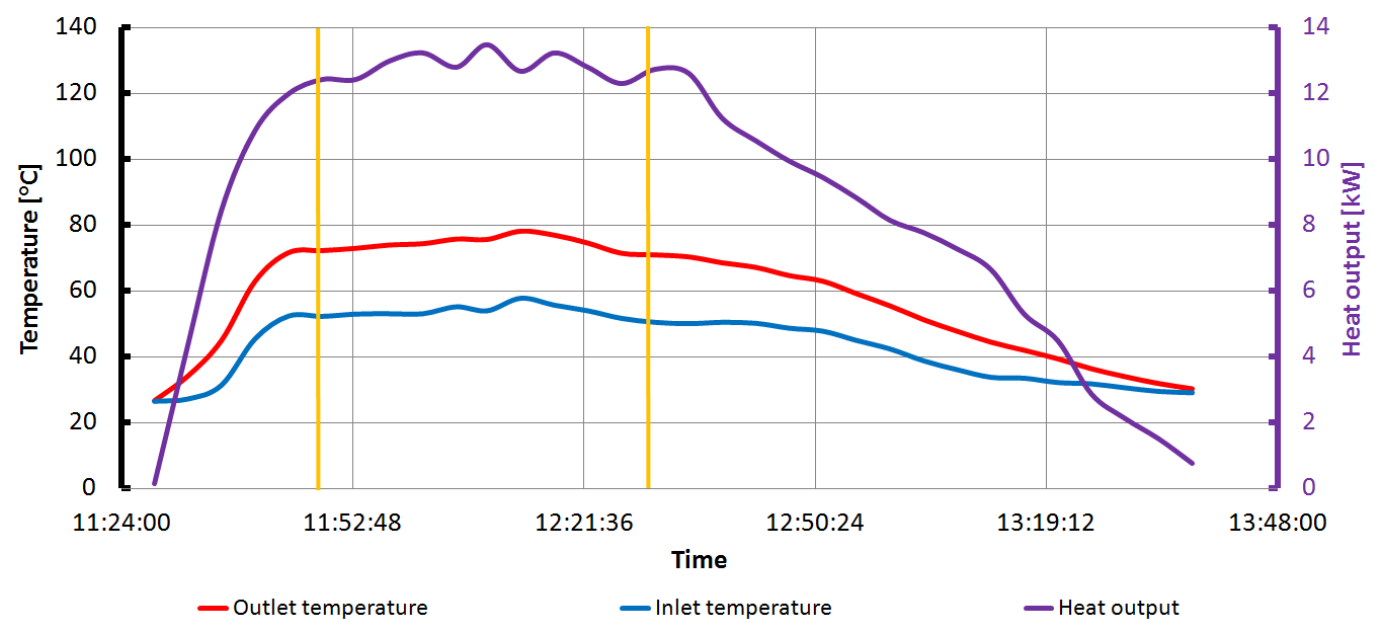

Figure 10. The operation parameters of the system and heat output of the boiler achieved during the combustion of beech wood billet. The yellow lines indicate the dust measurement period.

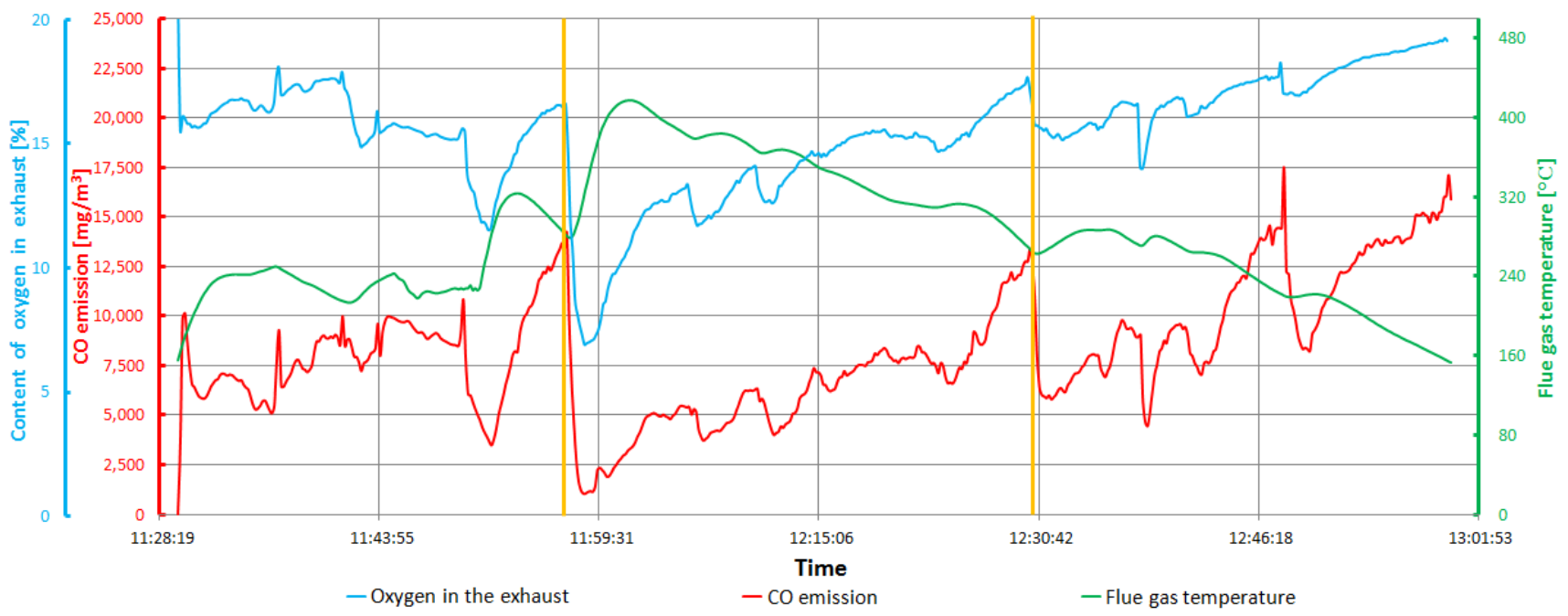

Figure 11. The oxygen in the exhaust and $\mathrm{CO}$ emission relative to $10 \%$ oxygen content in flue gas, beech wood billet. The yellow lines indicate the period of dust measurement. 
During the entire process of combustion, the boiler operated at an average output of $8.93 \mathrm{~kW}$, and the period of operation at the rated output was approximately $46 \mathrm{~min}$. This means the longest time of operation with an output close to the rated one among all the types of wood burnt. At the end of the process of combustion, degassed char with a mass of $0.64 \mathrm{~kg}$ and parameters similar to those of charcoal remained on the grate. The heat supplied to the system was $72.36 \mathrm{MJ}$, as compared with the theoretical chemical energy contained in the fuel) of $146.68 \mathrm{MJ}$, which allows the efficiency of the boiler during combustion of beech wood to be determined at $49.33 \%$.

The CO emissions with reference to an oxygen concentration in the flue gas of $10 \%$ range from $1040 \mathrm{mg} / \mathrm{m}^{3}$ at the most intense combustion to $17,476 \mathrm{mg} / \mathrm{m}^{3}$ when the fuel is extinguished (Figure 11). The average result from the whole process was $8217 \mathrm{mg} / \mathrm{m}^{3}$. Particulate matter emission (measured in a time period marked with vertical yellow lines on the graphs) was $182.2 \mathrm{mg} / \mathrm{m}^{3}\left(10 \% \mathrm{O}_{2}\right.$ ref.).

\section{Discussion and Conclusions}

As can be seen from the physicochemical analyses, all of the types of woody biomass in the study were characterised by similar values of each physicochemical parameter (Figure 12). The pine wood sample had the lowest moisture content at $10.05 \%$, while the beech wood sample had the highest at $12.5 \%$. It can be concluded that the pine wood was subjected to a longer drying process. All the fuels can be classified as air-dry wood. Birch and beech wood samples showed the lowest ash content, below $1 \%$. Each type of biomass in the test had a volatile content above $74 \%$. The highest value was recorded for pine at $76.87 \%$, the lowest for beech at $74.17 \%$. During combustion, it could be observed that fuels with a higher volatile matter content ignited faster and burnt more intensely, which may also be due to their lower density. The net calorific value of each fuel was approximately $16 \mathrm{MJ} / \mathrm{kg}$.

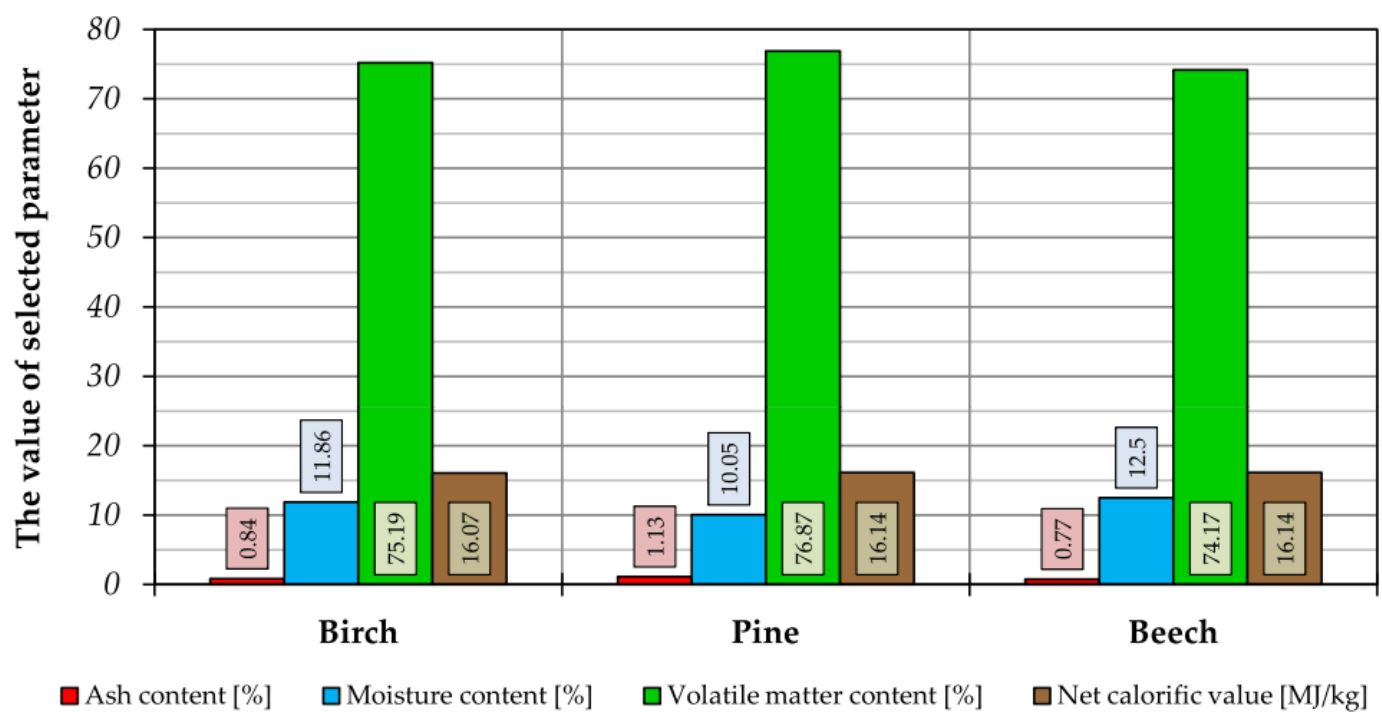

Figure 12. Summary of average physicochemical parameters of the three types of wood billets tested.

According to the rating plate on the boiler, its efficiency in nominal conditions should be close to $78 \%$ when it is fired with coal. Based on the tests carried out, it was found that the efficiency of the device is markedly lower when it is fired with woody biomass (Table 7). This is perfectly understandable in view of the fact that the tests were not carried out under the rated working conditions of the boiler as specified by the manufacturer. In addition, the fuel used for the process is not the recommended type of energy carrier for this device, but many users of such type boiler combusted coal and wood billets alternately. 
Table 7. Summary of the efficiency achieved by the boiler during combustion of wood.

\begin{tabular}{ccccc}
\hline Parameter & Unit & Birch & Pine & Beech \\
\hline Energy supplied to the system & MJ & 87.36 & 72.85 & 72.36 \\
Chemical energy in the wood supplied & MJ & 160.70 & 161.40 & 146.68 \\
Efficiency & $\%$ & 54.13 & 45.13 & 49.33 \\
\hline
\end{tabular}

The highest efficiency achieved by the device was $54.13 \%$ when burning birch wood. Beech wood was burnt with an efficiency lower by almost $5 \%$, i.e., $49.33 \%$. The lowest efficiency was recorded for pine- $45.13 \%$. Such a low efficiency as compared with the rated efficiency of the boiler is due to the fuel characteristics, boiler design, and combustion conditions. Wood is characterised by a very high volatile content. With regard to an updraft batch boiler, due to its design and short flue gas recirculation path, wood burns very quickly during operation with the fan on, which results in degassing in a short period of time of a very large portion of the volatile components contained in the fuel that are not post-combusted due to the lack of secondary air supply. A great deal of the energy they contain is emitted with flue gas into the atmosphere through the chimney in the form of smoke. An additional contributing factor is the low temperature in the combustion chamber. This is particularly noticeable when fuel is being added from the top. As a result of this process, the fire is suppressed, the temperature drops, and the volatile components of the fresh fuel immediately start to degas, and the water contained in the fuel evaporates, which results in a visible cloud of smoke and steam coming out of the chimney. Controlling the combustion process in such a boiler is extremely difficult, sometimes even impossible. There is no possibility to adjust the fan output, which results in a very high proportion of oxygen in the flue gas when there is less fuel on the grate. The air-fuel (lambda) ratio during the process of combustion ranged from 3 to even 9. This contributes to a large extent to an increase in CO emissions but only with respect to $10 \%$ of the oxygen content in the flue gases, which results from the specification of the process of calculation. Another factor that makes it difficult to control the process is the impossibility of effectively suppressing the combustion process when the critical operating temperatures of the system are reached. It is obviously possible to cut off the primary air supply by switching off the fan, but this is very inefficient and involves huge energy losses and a significant increase in emissions. This is caused by fuel combustion with insufficient oxygen $(\lambda<1)$, the result of which is incomplete fuel combustion that produces a large amount of $\mathrm{CO}$, and the combustible substance is not oxidised and settles in the ash pan with the ash, or is emitted into the atmosphere together with the flue gases.

When analysing the combustion process, it was found that wood with a lower density and a higher proportion of volatile components (birch and pine) burns much faster than fuels with higher density. This translates into a faster increase in boiler temperature and earlier achievement of the rated heat output. However, this is associated with significant energy losses as the boiler, due to its design, is not able to fully absorb the heat thus obtained. This translates into a rapid drop in the heat output of the device and lower efficiency. In the case of beech wood, the fuel burnt slowly, with a smaller flame, but this allowed the boiler to operate longer at the rated output and to maintain a high temperature of the medium flowing through the system compared with the same amount of pine or birch wood. This may also have been due to the much larger size of the wood billets as well as a lower proportion of combustible volatiles than in the case of softwood and light hardwood. It can therefore be concluded that this type of wood is better suited for combustion with the longer operation of the device, while lighter wood is ideal as a fire starter. However, looking at the results obtained, birch wood seems to be a suitable alternative to beech wood, but it requires more frequent feeding of fuel. The emission tests showed that in the case of combustion of woody biomass, the updraft batch boiler in the study is characterised by high emission of harmful substances and particulate matter (Figure 12). Birch wood had the highest average emission of CO, i.e., $9495 \mathrm{mg} / \mathrm{m}^{3}(10 \%$ $\mathrm{O}_{2}$ ref.). Beech wood was second, with CO emissions at $8217 \mathrm{mg} / \mathrm{m}^{3}\left(10 \% \mathrm{O}_{2}\right.$ ref.). Pine 
wood showed the lowest $\mathrm{CO}$ emissions at $7684 \mathrm{mg} / \mathrm{m}^{3}\left(10 \% \mathrm{O}_{2}\right.$ ref.). High values of $\mathrm{CO}$ emissions were recorded when fresh fuel was added. This is due to the fact that when fresh fuel is supplied from the top, it immediately starts to draw energy from the hot embers and degasify, which results in a drop in the temperature, which is followed by the process of reduction. As a result, $\mathrm{CO}$ is produced. There is also a sharp drop in oxygen content of the flue gas. The second stage, when carbon monoxide emissions are at their highest, is when the fuel burns out. A significant increase in the proportion of oxygen in the flue gas means that the primary air supplied is not used in the process of combustion. It can therefore be concluded that there is only a small amount of glowing fuel left on the grate. As a result of supplying an excessive amount of air, it is cooled down. In effect, the process of reduction begins to dominate relative to the process of combustion. This is best seen in the graphs showing $\mathrm{CO}$ emissions. Looking at the emission results presenting $\mathrm{CO}$, a certain regularity can be noticed, namely the increase in flue gas temperature (which marked the higher combustion temperature) when the $\mathrm{CO}$ emission decreases. It was observed in every case (Figures 7, 9 and 11). High flue gas temperature (over $160{ }^{\circ} \mathrm{C}$ ) shows that the heat exchange surface is not enough to effective flue gas cooling when the wood is combusted (with bigger flame than for coal).

This is best seen when the device operates at the rated output, and the flame in the combustion chamber is at its highest. The combustion process takes place more efficiently then, and the temperature in the furnace is higher. In effect, carbon monoxide, which has a high calorific value, is oxidised to $\mathrm{CO}_{2}$ more easily, which is also due to the influence of temperature [29]. However, parallel heat exchange surface is too small to effectively coll down the fumes. A sharp drop in the oxygen content of the flue gases can then be observed. It follows that the application of a solution such as a heat buffer has a favourable effect on the quality of the process of combustion and contributes to reducing emissions of carbon monoxide. With regard to particulate matter emissions, the highest value was recorded for beech wood, i.e., $182.2 \mathrm{mg} / \mathrm{m}^{3}$, followed by birch at $152 \mathrm{mg} / \mathrm{m}^{3}$, and the lowest for pine at $116.9 \mathrm{mg} / \mathrm{m}^{3}$. In the case of beech wood, the high emission value is due to incomplete oxidation of the fuel, resulting from the lower temperature in the combustion chamber and the impossibility of burning off dust, which was in turn due to smaller flame than in the other cases. This was confirmed by the fact that beech wood had the lowest ash content of all the samples, which was revealed in the physicochemical analysis. Based on the PN:EN 303-5:2002 standard [23] relating to emission values during boiler operation at the rated output, it can be concluded that in the case of burning each type of wood, the emission values meet the requirements for Class 1 for either $\mathrm{CO}$ or particulate matter (according to rating plate) (Table 8). However, given the low efficiency of the boiler when burning wood, it could not be assigned to any class regardless of the emission values.

Table 8. Comparison of the obtained emission values with the Ecodesign requirements.

\begin{tabular}{ccccccc}
\hline $\begin{array}{c}\text { Type of Emission at } \\
\text { Operation at Rated } \\
\text { Output-Ref. } \mathbf{O}_{\mathbf{2}}=\mathbf{1 0} \%\end{array}$ & Unit & Birch & Pine & Beech & $\begin{array}{c}\text { PN-EN 303-5:2002 } \\
\text { Requirement-Class 1 }\end{array}$ & $\begin{array}{c}\text { PN-EN 303-5:2012 } \\
\text { Requirement-Class 5 }\end{array}$ \\
\hline CO & $\mathrm{mg} / \mathrm{m}^{3}$ & 7126 & 5196 & 3497 & 25,000 & 700 \\
Particulate matter & $\mathrm{mg} / \mathrm{m}^{3}$ & 182.2 & 152.0 & 116.9 & 200 & 60 \\
\hline
\end{tabular}

Based on the above research, it was found that outdated batch boilers show $\mathrm{CO}$ and dust emissions that are even several times higher than in the case of devices meeting requirements for Class 5 according to PN:EN 303-5:2012 [6] (Table 8), which definitely contributes to the phenomenon of emissions from low stack. For short-term operations, they are also characterised by very low efficiency. In order to determine the seasonal efficiency of a boiler, tests should be carried out over a longer period of time, under the rated operating conditions. Other disadvantages of this type of boiler are the difficulties associated with their operation and maintenance. 
Finally, it should also be mentioned that co-current combustion (downdraft boilers), i.e., where the fuel is burnt from the bottom and the primary air for the process is supplied towards the embers, from the cooler layers of the fuel, is also possible in batch boilers. This way is more difficult to control, but studies confirm that it has a beneficial effect on reducing emissions and increasing the efficiency of the device itself [21]. However, this does not change the fact that it is necessary to replace these devices with newer ones that meet the most stringent standards and requirements, such as Class 5 and Ecodesign requirements for boilers, which is anyway determined by the pro-environmental policy in Poland.

Author Contributions: Conceptualization, P.P.; methodology, G.P. and W.L.; software, G.P. and W.L.; validation, W.L.; formal analysis, P.P. and G.P.; investigation, P.P. and W.L.; resources, G.P. and W.L.; data curation, G.P.; writing-original draft preparation, A.J., M.P., P.W. and M.W.; writing-review and editing, A.J., M.P., P.W., M.W. and J.K.; visualization, P.P. and M.W.; supervision, G.P. and A.J.; project administration, G.P.; funding acquisition, P.P., G.P., W.L., A.J., P.P., P.W., M.W. and J.K. All authors have read and agreed to the published version of the manuscript.

Funding: This research was funded by the statutory research program at the Faculty of Geology, Geophysics and Environmental Protection, AGH University of Science and Technology in Krakow, Poland, Statutory Work No. 16.16.140.315/05 and Cracow University of Economics founds.

Data Availability Statement: Not applicable.

Acknowledgments: Not applicable.

Conflicts of Interest: The authors declare no conflict of interest.

\section{References}

1. Kaczmarczyk, M.; Pełka, G.; Luboń, W.; Będkowska, A.; Piechowicz, Ł.; Ciapała, B.; Blok, M. Low Emission: From Its Sources to the Means of Elimination; Geosystem Burek, Kotyza S.C.: Krakow, Poland, 2015; pp. 1-134.

2. Adamczyk, J.; Piwowar, A.; Dzikuć, M. Air protection programmes in Poland in the context of the low emission. Environ. Sci. Pollut. Res. 2017, 24, 16316-16327. [CrossRef]

3. Dzikuć, M. The Economic and Social Factors of Low Emission Reduction in Poland, 1st ed.; Difin: Warsaw, Poland, $2017 ;$ pp. 1-175.

4. KOBiZE. Krajowy Raport Inwentaryzacyjny 2018. Inwentaryzacja Gazów Cieplarnianych w Polsce dla lat 1988-2016; Raport syntetyczny; Krajowy Ośrodek Bilansowania i Zarządzania Emisjami: Warszawa, Poland, 2018.

5. Uchwała Nr XXXII/452/17 Sejmiku Województwa Małopolskiego z dnia 23 Stycznia 2017 r. w Sprawie Wprowadzenia na Obszarze Województwa Małopolskiego Ograniczeń i Zakazów w Zakresie Eksploatacji Instalacji, w Których Następuje spalanie Paliw (Dz.U. WOJ. 2017.787). Available online: https:/ / bip.malopolska.pl/umwm,a,1283900, uchwala-nr-xxxii45217-sejmikuwojewodztwa-malopolskiego-z-dnia-23-styczna-2017-r-w-sprawie-wprowadze.html (accessed on 8 September 2021).

6. PN-EN 303-5: 2012. Kotły Grzewcze-Część 5: Kotły Grzewcze na Paliwa Stałe z Ręcznym i Automatycznym Zasypem Paliwa o Mocy Nominalnej do 500 kW-Terminologia, Wymagania, Badania i Oznakowanie. Available online: https://powietrze. malopolska.pl/wp-content/uploads/2017/12/wymagania-dla-kotlow-na-paliwa-stale1.pdf (accessed on 25 September 2021).

7. Wyczesany, P. Innowacyjna metoda autotermicznej waloryzacji biomasy. In Innowacyjność Jako Narzędzie Kreowania Jakości, Instytut Technologii Eksploatacji-Państwowy Instytut Badawczy; Cholewa-Wójcik, A., Kawecka, A., Eds.; Instytut Technologii Eksploatacji-Państwowy Instytut Badawczy: Radom, Poland, 2019; pp. 87-97.

8. Wyczesany, P. Innowacyjna technologia jako narzędzie do zwiększenia udziału biomasy w polskim bilansie energetycznym. In Wiedza, Gospodarka, Społeczeństwo: Innowacje i Rachunkowość na Drodze Cyfrowej Transformacji Gospodarki, Towarzystwo Naukowe Organizacji i Kierownictwa; Jaki, A., Nesterak, J., Eds.; Towarzystwo Naukowe Organizacji i Kierownictwa. Dom Organizatora: Torun, Poland, 2020; pp. 163-174.

9. Maxwell, D.; Gudka, B.A.; Jones, J.M.; Williams, A. Emissions from the combustion of torrefied and raw biomass fuels in a domestic heating stove. Fuel Process. Technol. 2020, 199, 1-9. [CrossRef]

10. Ozgen, S.; Cernuschi, S.; Caserini, S. An overview of nitrogen oxides emissions from biomass combustion for domestic heat production. In Renewable and Sustainable Energy Reviews; Elsevier B.V., Ed.; Elsevier: Amsterdam, The Netherlands, 2021; Volume 135. [CrossRef]

11. Price-Allison, A.; Mason, P.E.; Jones, J.M.; Barimah, E.K.; Jose, G.; Brown, A.E.; Williams, A. The Impact of Fuelwood Moisture Content on the Emission of Gaseous and Particulate Pollutants from a Wood Stove. Combust. Sci. Technol. 2021, 1-20. [CrossRef]

12. Lv, T.; Yu, L.; Song, J. A research of simplified method in boiler efficiency test. Energy Procedia 2012, 17, 1007-1013. [CrossRef]

13. Chang, L. Optimized operation of boiler. In Advanced Materials Research; Trans Tech Publications Ltd.: Freienbach, Switzerland, 2014; pp. 960-961.

14. Szubel, M.; Filipowicz, M. Analiza numeryczna pracy urządzeń grzewczych małej mocy zasilanych biomasa [The numerical analysis of operation of the small-Scale biomass heating devices]. J. Civ. Eng. Environ. Archit. 2015, 62, 477-486. 
15. Wasilewski, A. Sprawność kotłów wczoraj i dziś [The efficiency of boilers yesterday and today]. Install Rep. $2017,12,43$.

16. Mateja, B. Problematyka środowiskowa w zarządzaniu organizacją wobec koncepcji zrównoważonego rozwoju. In Book Wybrane Problemy Nauk o Zarządzaniu i Jakości; Borowiec, A., Ed.; Instytut Naukowo-Wydawniczy, Spatium: Radom, Poland, 2020; Volume 8, pp. 131-144.

17. Kowalska, F. Zanieczyszczenie powietrza istotnym zagrożeniem dla zdrowia mieszkańców polskich miast [Air pollution is a significant threat to the health of the inhabitants of Polish cities]. Refleksje Pismo Nauk. Stud. I Dr. WNPiD UAM 2020, $21,71-83$. [CrossRef]

18. Ustawa z Dnia 27 Kwietnia 2001 r. Prawo Ochrony Środowiska. (Dz.U. z 2020 r. poz. 2127). Available online: https: / /isap.sejm.gov.pl/isap.nsf/DocDetails.xsp?id=WDU20010620627 (accessed on 8 September 2021).

19. Directive 2008/50/EC of the European Parliament and of the Council of 21 May 2008 on Ambient Air Quality and Cleaner Air for Europe (Dz.U. UE 2008 L 152/1). Available online: https:/ / eur-lex.europa.eu/legal-content/en/TXT/?uri=CELEX\%3A32008L0 050 (accessed on 8 September 2021).

20. KPOP. Krajowy Program Ochrony Powietrza Do Roku 2020 (z Perspektywa Do Roku 2030); Ministerstwo Środowiska, Departament Ochrony Powietrza: Warszawa, Poland, 2015.

21. Kaczmarczyk, M.; Pełka, G.; Luboń, W.; Będkowska, A.; Ciapała, B.; Malik, D.; Podlewska, E.; Zboina, M. Low Emission: Energy Efficiency in Municipalities and Local Governments; Globenergia Sp. z o.o.: Kraków, Poland, 2017; pp. 1-135.

22. PN-70/H-83136:1970. Kotły Grzewcze. Nazwy i Określenia. (The Standard Withdrawn: 6 October 2005 r.). Available online: https:/ / sklep.pkn.pl/pn-h-83136-1970p.html (accessed on 5 May 2021).

23. PN-EN 303-5:2002. Kotły Grzewcze. Część 5: Kotły Grzewcze na Paliwa Stałe z Ręcznym i Automatycznym Zasypem Paliwa o Mocy Nominalnej do 300 kW. Terminologia, Wymagania, Badania i Oznakowanie. Available online: https:/ / niskaemisja.ekoscan. pl/8-aktualnosci/106-kotly-weglowe-na-5-klasa-w-teorii-i-praktyce (accessed on 11 July 2021).

24. Rozporządzenie Ministra Rozwoju i Finansów z Dnia 1 Sierpnia 2017 r. w Sprawie Wymagań dla Kotłów na Paliwo Stałe (Dz.U. 2017 poz. 1690). Available online: http:/ /isap.sejm.gov.pl/isap.nsf/DocDetails.xsp?id=WDU20170001690 (accessed on 20 July 2021).

25. Rozporządzenie Ministra Przedsiębiorczości i Technologii z dnia 21 Lutego 2019 r. Zmieniające Rozporządzenie w Sprawie Wymagań dla Kotłów na Paliwo Stałe (Dz.U. 2019 poz. 363). Available online: http:/ /isap.sejm.gov.pl/isap.nsf/DocDetails.xsp? id=WDU20190002549 (accessed on 20 July 2021).

26. Directive 2009/125/EC of the European Parliament and of the Council of 21 October 2009 Establishing a Framework for the Setting of Ecodesign Requirements for Energy-Related Products (recast) (Text with EEA Relevance) (Dz.U. UE z 2009 r. L 285/10). Available online: https:/ / eur-lex.europa.eu/legal-content/EN/ALL/?uri=celex\%3A32009L0125 (accessed on 20 July 2021).

27. Sawiński, T. Uwaga! Od 1 Stycznia Wyłącznie Ekoprojekt! Available online: https://mappingair.meteo.uni.wroc.pl/2019/12/ uwaga-od-1-stycznia-wylacznie-ekoprojekt/ (accessed on 7 July 2021).

28. Variny, M.; Varga, A.; Rimár, M.; Janošovský, J.; Kizek, J.; Luká, L.; Jablonský, G.; Mierka, O. Advances in Biomass Co-Combustion with Fossil Fuels in the European Context: A Review. Processes 2021, 9, 100. [CrossRef]

29. Wach, E. Właściwości granulatu drzewnego. Czysta Energ. 2005, 6, 35.

30. Pełka, G.; Luboń, W. Przegląd technologii kotłów na biomasę małej mocy. GLOBEnergia 2011, 2, 46-49.

31. Kapuśniak, J. Kotły na zgazowanie drewna. GLOBenergia 2009, 4, 44-45.

32. Kubica, K. Efektywne i Przyjazne Środowisku Źródła Ciepła-Ograniczenie Niskiej Emisji. Poradnik; Polski Klub Ekologiczny Okręg Górnośląski: Katowice, Poland, 2007; pp. 1-49.

33. Nussbaumer, T.; Czasch, C.; Klippel, N.; Johansson, L.; Tullin, C. Particulate Emissions from Biomass Combustion in IEA Countries; International Energy Agency (IEA) Bioenergy Task 32; Swiss Federal Office of Energy (SFOE): Zurich, Switzerland, 2008; Available online: http:/ / www.verenum.ch/Publikationen/IEAReportPM10Jan08.pdf (accessed on 20 July 2021).

34. Jak Palić Drewnem. Available online: https:/ / czysteogrzewanie.pl/ (accessed on 20 July 2020).

35. Pełka, G.; Luboń, W. Analiza wpływu surowców na technologię produkcji biopaliw stałych [Technologies used for producing pellets and briquettes]. GLOBEnergia 2011, 1, 47-49.

36. Bonder, L.; Mirosz, M. Przegląd technologii zgazowania biopaliw stałych. Instal 2007, 11, 10-15.

37. GUS Statistics Poland. Zużycie Energii w Gospodarstwach Domowych w 2018 r. [Energy Consumption in Households in 2018]; Warsaw, Poland, 2019; pp. 1-27. Available online: https://stat.gov.pl/download/gfx/portalinformacyjny/pl/defaultaktualnosci/5485/2 /4/1/zuzycie_energii_w_gospodarstwach_domowych_w_2018.pdf (accessed on 28 July 2021).

38. Kraszkiewicz, A. Analiza wybranych właściwości chemicznych drewna i kory robinii akacjowej (Robinia pseudoacacia L.) [Analysis of selected chemical properties of black locust (Robinia pseudoacacia L.) wood and bark]. Inżynieria Rol. 2009, 13, 69-75.

39. Kubiak, M.; Laurow, Z. Surowiec Drzewny; Fundacja, Rozwój SGGW: Warszawa, Poland, 1994.

40. Klonowski, A. Spalanie i Analiza Spalin-Część 1. Available online: https:/ / www.merserwis.pl/ (accessed on 20 August 2021).

41. Khodaei, H.; Guzzomi, F.; Yeoh, G.H.; Regueiro, A.; Pati, D. An experimental study into the effect of air staging distribution and position on emissions in a laboratory scale biomass combustor. Energy 2016, 118, 1243-1255. [CrossRef]

42. Kubica, K. Toxic oragnic pollutants form small combustion installations and pyrolysis experiment. In Proceedings of the ICCS\&T, Nottingham, UK, 28-31 August 2007. 
43. Radsak, D. Redukcja emisji tlenków azotu w kotłach energetycznych jako konieczność spełnienia europejskich standardów emisyjnych [Reduction of nitrogen oxides emissions in power boilers connected with european legal requirements]. Pozn. Univ. Technol. Acad. J. Electr. Eng. 2017, 90, 333-345.

44. Dzurenda, L.; Orłowski, K. The effect of thermal modification of ash wood on granularity and homogeneity of sawdust in the sawing process on a sash gang saw PRW 15-M in view of its technological usefulness. DREWNO 2011, 54, 186.

45. Hill, S.C.; Smoot, L.D. Modeling of nitrogen oxides formation and destruction in combustion systems. Prog. Energy Combust. Sci. 2000, 26, 417-458. [CrossRef]

46. Zajemska, M.; Poskart, A.; Musiał, D. Kinetyka tlenków azotu powstawania w gazie płomieniowym. Econ. Environ. Stud. 2020, $15,445-461$.

47. Wach, E. Możliwości Wykorzystania Granulatu Drzewnego w Województwie Pomorskim. Materiały Konferencyjne: Bałtycka Agencja Poszanowania Energii SA [Proceedings of the BAPE]. 2002. Available online: http://bape.com.pl/publikacje/ (accessed on 5 August 2021).

48. Łapiński, K. Poradnik Modelarza Lotniczego; Wydawnictwa Komunikacji Łacznności: Warszawa, Poland, 1984.

49. Guzenda, R.; Świgoń, J. Techniczne i ekologiczne aspekty energetycznego wykorzystania drewna i odpadów drzewnych. Gospod. Paliwami I Energia 1997, 45, 10-12.

50. Różycki, A.W.; Szramka, R. Energia Geotermalna. Biul. Urzędu Regul. Energetyki 1999, 3, 17-27.

51. Rocznik Statystyczny Leśnictwa 2020; Główny Urząd Statystyczny: Warszawa, Poland, 2020.

52. Konieczny, A. Raport o Stanie Lasów w Polsce 2018; Państwowe Gospodarstwo Leśne Lasy Państwowe: Warszawa, Poland, 2019.

53. Informacje Techniczne, Instrukcja Montażu i Obsługi (DTR), [Technical Information, Assembly and Operating Manual (O\&M Manual)]. Available online: http:/ /www.ogniwobiecz.com.pl/wp-content/uploads/2016/08/DTR-S6WC-Classic_wer._02_ 2016.pdf (accessed on 4 September 2021).

54. Poradnik Zakupowy-Zanim Kupisz [Buying Guide-Before You Buy]. Available online: http://www.drewno-kluczynski.pl/ (accessed on 20 July 2020).

55. Charakterystyka Biomasy [Characteristics of Biomass]. Available online: http:/ /www.instsani.pl/ (accessed on 20 July 2020).

56. Górecki, W.; Kotyza, J.; Hałaj, E.; Luboń, W.; Pełka, G.; Sowiżdżał, A.; Dawiec, D.; Smaczna, P.; Malik, D. Education and research in the field of renewable sources of energy in the Centre of Sustainable Development and Energy Savings WGGIOS AGH in Miekinia. In E3S Web of Conferences; EDP Sciences: Paris, France, 2020; Volume 154.

57. Pełka, G.; Luboń, W.; Pachytel, P. Analysis of the efficiency of a solid fuel boiler depending on the choice of combusted fuel. In E3S Web of Conferences; EDP Sciences: Paris, France, 2020; Volume 154. [CrossRef]

58. Jach-Nocoń, M.; Pełka, G.; Luboń, W.; Mirowski, T.; Nocoń, A.; Pachytel, P. An Assessment of the Efficiency and Emissions of a Pellet Boiler Combusting Multiple Pellet Types. Energies 2021, 14, 4465. [CrossRef]

59. Pełka, G.; Luboń, W.; Kotyza, J.; Malik, D.; Jastrzębski, P. Design and development of a didactic mobile installation with solid fuel boilers and a heat pump. In Renewable Energy Sources: Engineering, Technology, Innovation: ICORES 2017; Mudryk Krzysztof, W.S., Ed.; Springer International Publishing AG: Basel, Switzerland, 2017; pp. 503-510. [CrossRef]

60. Testo 350-Flue Gas Anaylzer. Manual. Available online: https://static-int.testo.com/media/7c/b1/f2f2baf6ab2a/testo-350-SInstruction-Manual.pdf (accessed on 8 September 2021). (In Polish).

61. Goryl, W.; Filipowicz, M. Metody wykorzystywane w suszeniu biomasy [Methods used in biomass drying]. Czas. Inżynierii Ladowej Sr. I Archit. 2016, 63, 151-158.

62. Boundy, B.; Diegel, S.; Wright, L.; Davis, S. The Effect of Moisture on Heating Values, In Biomass Energy Data Book, 4th ed.; Sokhansanj, S., Ed.; Oak Ridge National Laboratory: Oak Ridge, TN, USA, 2011.

63. Jagustyn, B.; Bątorek-Giesa, N.; Wilk, B. Ocena właściwości biomasy wykorzystywanej do celów energetycznych. CHEMIK 2011, $65,557-563$.

64. Tosti, L.; van Zomeren, A.; Pels, J.R.; Comans, R.N.J. Evaluating Biomass Ash Properties as Influenced by Feedstock and Thermal Conversion Technology towards Cement Clinker Production with a Lower Carbon Footprint. Waste Biomass Valorization 2021, 12, 4703-4719. [CrossRef]

65. Agalit, H.; Zari, N.; Maaroufi, M. Suitability of industrial wastes for application as high temperature thermal energy storage (TES) materials in solar tower power plants-A comprehensive review. Sol. Energy 2020, 208, 1151-1165. [CrossRef]

66. Bennack, V.; Dalla Valentina, L.V.O.; Folgueras, M.V. Analysis of Technical Suitability of Using Wood Ash in Cement Based Materials. Mater. Sci. Forum 2016, 881, 341-345. [CrossRef]

67. EN 14775:2009. Solid Biofuels-Determination of Ash Content. Available online: https://infostore.saiglobal.com/preview/is/en/ 2009/i.s.en14775-2009.pdf?sku=1382258 (accessed on 25 September 2021).

68. PN-G-04516:1998. Paliwa Stałe-Oznaczanie Zawartości Części Lotnych Metodą Wagowa. Available online: https://sklep.pkn.pl/ pn-g-04516-1998p.html (accessed on 25 September 2021).

69. Ekontrol Software. Available online: https:/ / ekontrol.pl/ (accessed on 20 July 2020). 